\title{
Ellen Smith-Dennis*
}

\section{Don't feel obligated, lest it be undesirable: the relationship between prohibitives and apprehensives in Papapana and beyond}

\author{
https://doi.org/10.1515/lingty-2020-2070
}

Received May 31, 2019; accepted February 1, 2020; published online January 22, 2021

\begin{abstract}
This paper analyses the preverbal morpheme te, used in both apprehensive 'precautioning' sentences and in one of two prohibitive constructions in Papapana (papa1265, Austronesian, Oceanic; Papua New Guinea). I aim to establish whether there is a diachronic relationship between the two functions of te, and in which direction, how and why semantic change may have occurred. This requires consideration of the synchronic differences between Papapana prohibitives, comparisons with apprehensive and prohibitive constructions in other Oceanic languages, and an investigation of other languages where apprehensive and prohibitive morphemes are formally similar/identical. I argue that the two functions of te are diachronically related, but not polysemous, and that the prohibitive meaning developed from the apprehensive meaning via insubordination. This supports Pakendorf, Brigitte \& Ewa Schalley's proposed pathway of development from possibility to prohibition, via apprehension and warning. However, I argue that their pathway does not, as claimed, run counter to the proposed grammaticalisation path of deontic to epistemic modality, because prohibitives are arguably not deontic. This paper contributes to the growing body of research on apprehensives, demonstrates that the pathway from apprehension to prohibition is perhaps not as rare as Pakendorf and Schalley thought, and contributes to research on language change and modality.
\end{abstract}

Keywords: apprehensive; deontic; insubordination; Oceanic; Papapana; precautioning; prohibitive

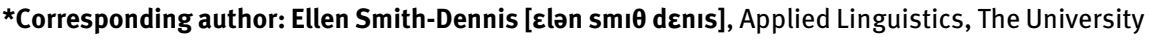
of Warwick, Coventry, CV4 7AL, England, E-mail: E.Smith-Dennis@warwick.ac.uk
} 


\section{Introduction}

Apprehensives express that a situation is possible, but judged to be undesirable. Apprehensives are widespread cross-linguistically but have, until recently, received little attention in typological and semantic literature. Lichtenberk (1995) delineated three functions of apprehensives: apprehensional-epistemic, fear, and precautioning. In the precautioning function, the apprehensive occurs in a complex sentence and encodes an "apprehension-causing" situation; such a clause is associated with a "precaution" main clause expressing preventative action which can be taken to avoid the undesirable situation. In some languages, apprehensives are formally similar/identical to prohibitives, constructions in which the speaker tries to make the addressee not do, or cease doing, something, yet this similarity has scarcely been addressed. In a typological sample of 163 languages, Pakendorf and Schalley (2007) found the use of apprehensive forms to express prohibitives rare, and propose that meanings of prohibition develop from meanings of possibility via apprehension and warning. Pakendorf and Schalley (2007) claim that this pathway runs counter to the development of deontic to epistemic modality proposed in the literature, since they consider possibility and prohibition to encode epistemic and deontic modality respectively.

This paper analyses the preverbal morpheme te, used in both precautioning sentences and prohibitive clauses in Papapana, a previously undocumented and under-described endangered Northwest Solomonic (Oceanic, Austronesian) language, spoken on Bougainville island, Papua New Guinea. There are two prohibitive constructions in Papapana: both involve verbal reduplication and optional use of irrealis $=i$, but the verb is preceded by $t e$ in one and by the negator $a e$ in the other. In Papapana precautioning sentences, te co-occurs with $=i$ in the apprehension-causing adverbial clause, while the precaution main clause is usually an imperative or prohibitive. This paper thus contributes to the growing body of research on precautioning sentences, paying particular attention to the syntactic status of the apprehension-causing clause, one of the main issues addressed in previous research. I then investigate whether there is a diachronic relationship between the two functions of te in Papapana and in which direction semantic change may have occurred: did a prohibitive morpheme gain an apprehensive meaning or did an apprehensive morpheme gain a prohibitive meaning? Since diachronic data for Papapana is lacking, this analysis involves consideration of the synchronic differences between prohibitives involving te and $a e$, and comparing apprehensive and prohibitive constructions in other Oceanic languages. It also involves consideration of the theoretical literature on language change to identify why and how this semantic change happened. 
I build on Pakendorf and Schalley's (2007) research by not only showing that there is formal similarity between apprehensives and prohibitives in Papapana, but in other languages of the Pacific too (where the morphemes in question are often polysemous), and by exploring whether or not the Papapana data supports Pakendorf and Schalley's (2007) proposed pathway of development from apprehension to prohibition.

Papapana speakers are based in six villages along Bougainville's northeast coast and at the time of writing, there are 99 fluent speakers, representing $17 \%$ of the villages' population. Papapana is spoken in the village domain, and occasionally in the first few years of school. Most fluent Papapana speakers are in their 30s or older. Papapana is evidently endangered and this is due to shift to Tok Pisin (tokp1240, English-based pidgin/creole; Papua New Guinea), which has been caused by a number of factors including European colonisation in 1886 and displacement during the Bougainville Crisis (1989-1997) (see Smith 2016b). Prior to colonisation, Papapana speakers mostly had contact with speakers of Rotokas (roto1249, Papuan; Bougainville, Papua New Guinea) for trade and intermarriage, whereas nowadays contact is extensive and with speakers of various Northwest Solomonic (NWS), Oceanic, and Papuan languages.

The Papapana analysis is based on a corpus of data I collected as part of a documentation and description project, involving 12 months' fieldwork in the Papapana community (June 2011-March 2012 and March-May 2013), and on further elicitation data I collected during a three-week visit in April 2018. In total, I collected $51 \mathrm{~h}$ of audio-recorded lexical and grammatical elicitation sessions and $10.5 \mathrm{~h}$ of audio- and/or video-recorded 'text' sessions, which were generally observed communicative events (such as traditional narratives) but also included staged communicative events (such as speakers describing procedures). The analysis is exemplified as much as possible by spontaneously produced utterances from text recordings (indicated by $T$ in the data reference), but elicited data have been used (indicated by $E$ ) when that was not possible or when they more clearly exemplify the analysis. The data references begin with the fieldwork trip number, then the session type $T$ or $E$, and session number. All data, including annotations and metadata, from my documentation and description project are archived with The Endangered Language Archive (ELAR) (Smith 2015). ${ }^{1}$

1 The collection can be accessed freely by any registered ELAR user from http://elar.soas.ac.uk/ deposit/0313. The annotation files require further work to make the orthography and word boundaries in the transcriptions more consistent, and the translations more accurate. Examples in this article have been amended in these areas. 
This paper first provides an overview of the areas of Papapana's grammar that are most relevant to the constructions analysed in this paper (Section 2). Section 3 explores apprehensives from a typological perspective, with a focus on Oceanic and NWS languages, and then analyses precautioning sentences in Papapana. Section 4 similarly examines prohibitives from a typological perspective, with a focus on Oceanic and NWS languages, before analysing prohibitive constructions in Papapana. Section 5 investigates non-Austronesian, Austronesian, and Oceanic languages where an apprehensive and prohibitive morpheme are formally similar/identical, exploring the relationship between these two meanings before considering the relationship between the use of $t e$ in apprehension-causing and prohibitive clauses in Papapana. Section 6 turns to Pakendorf and Schalley's (2007) proposed pathway of development and considers whether the Papapana data supports this pathway or not, and the motivations and mechanisms for this semantic change. Finally, an overall conclusion is presented in Section 7, where I argue that Pakendorf and Schalley's (2007) proposed pathway does not, as claimed, run counter to the proposed grammaticalisation path of deontic to epistemic modality, because prohibitives are arguably not deontic.

\section{Papapana grammatical overview}

This section provides an overview of the areas of Papapana's grammar that are most relevant to the constructions in this paper: its verbal morphology and clausal and sentential syntax, including adverbial clauses (Section 2.1); the tense, aspect and mood (TAM) system, including irrealis mood and reduplication (Section 2.2); and negation (Section 2.3). For more information, see Smith-Dennis (2020).

\subsection{The verb complex, clauses and complex sentences}

As per the Oceanic research tradition, the term verb complex (VC) is a descriptive device used to capture the fixed structural relationship between the verbal head and its accompanying modifiers. Tables 1 and 2 show Papapana's VC structure (tense, aspect, mood [TAM] and negative markers are in bold). Papapana is a nominative-accusative language, with core arguments indexed in the VC by obligatory subject proclitics, and object enclitics.

Clause order is variable and this is argued to be the result of Papuan contact (Smith 2016a). In intransitive clauses, verb-initial clause order is highly restricted, 
Table 1: Verb complex structure: preverbal.

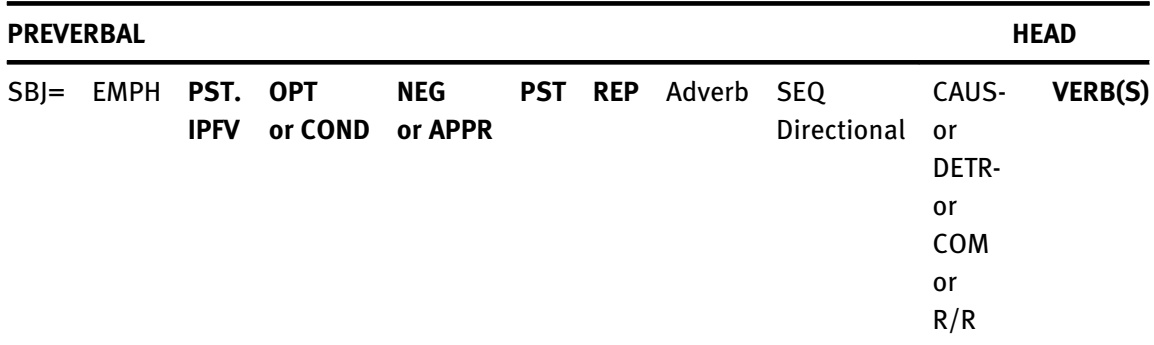

Table 2: Verb complex structure: postverbal.

\begin{tabular}{|c|c|c|c|c|c|c|c|c|c|}
\hline$\frac{\text { HEAD }}{\operatorname{VERB(S)}}$ & \multicolumn{9}{|c|}{ POSTVERBAL } \\
\hline VERB(S) & $\begin{array}{l}\text { Geocentric } \\
\text { Directional }\end{array}$ & $\begin{array}{l}\text { Allative } \\
\text { Directional }\end{array}$ & COMPL & Adverb & $\begin{array}{l}=\mathrm{TR} \\
\text { or } \\
\text { APPL }\end{array}$ & $=0 \mathrm{BJ}$ & $=\mathrm{PSI}$ & $\begin{array}{l}\text { Deictic } \\
\text { Directional }\end{array}$ & $=\mid R R$ \\
\hline
\end{tabular}

Transitive $=i$ and applicative $i$ only occur with singular objects and certain verbs.

while in transitive clauses, both subject-verb-object (SVO) and subject-objectverb (SOV) order are prevalent. There is a clause initial Topic position.

Verbs do not have to be marked for TAM, so finiteness is determined by the presence of subject-indexing proclitics. Adverbial clauses are either (i) non-finite and introduced by a subordinator (1), (ii) finite but the specific combination of mood markers, such as $a w a$ and $=i$, does not occur in independent clauses (2), or (iii) finite and introduced by a subordinator (3)-(4). Subordinators do not occur in independent clauses, and the subordinate clause they mark may precede (4) or follow (3) the main clause.

$$
\begin{aligned}
& \text { Reareana } i=\text { pei } \quad n a o=i \text { tena vono=ina na }=\text { vanua }^{2} \\
& \text { far 3PL.SBJ=PST.IPFV go=IRR SUBR hunt=3PL.OBJ SPEC[CLI]=people }{ }^{3} \\
& \text { 'They used to go far away in order to hunt humans.' } \\
& \text { (1-T021) }
\end{aligned}
$$

2 All orthographic symbols have their expected IPA values, except $n g=/ \mathrm{n} /, r=/ \mathrm{r} /, \nu=/ \beta /$, and ${ }^{\prime}=/ \mathrm{R} /$. Data from other languages is presented in the orthography used by the respective authors.

3 In data from other languages, I mostly maintain the abbreviations used by the authors. However, I made some changes to be consistent across all data or to align with Leipzig glossing rules. As per Leipzig glossing conventions, a reduplicant and base are separated by $\sim$, but like other authors, I have not followed the Leipzig practice of giving a semantically specific gloss for the reduplicant; instead it is glossed as $R D$. A list of abbreviations is at the end of this paper. 
(2) $\boldsymbol{O}=$ to

$$
\begin{array}{lll}
\boldsymbol{a w a} & \boldsymbol{n a o}=\boldsymbol{i}, & i=\text { no } \\
\text { COND } & \text { go }=\mathrm{IRR} & \text { 3PL.SBJ }=\text { go.SEQ }
\end{array}
$$

atun $=i=0=i$.

2SG.SBJ=EMPH

attack $=\mathrm{TR}=2 \mathrm{SG} . \mathrm{OBJ}=\mathrm{IRR}$

'If you go, they will go and attack you.'

(2-E022)

(3)

$$
\begin{array}{lll}
\ldots i=\text { vamamatau }=\text { ina }=i & \text { oina }=\text { bau } & \text { 'usia }, \\
\text { 3PL.SBJ=teach=3PL.OBJ=IRR } & \text { 3PL.PSSR=PL } & \text { child }
\end{array}
$$

$\begin{array}{llllll}\text { marana } & \text { aina } & \boldsymbol{i}=\text { to } & \text { nai }=\text { ina } & \text { nao } & \text { na:=bau } \\ \text { even.though } & \text { 3PL } & \text { 3PL.SBJ=EMPH } & \text { marry=3PL.OBJ } & \text { thither } & \text { Some }=\text { PL }\end{array}$

i-ota.

LOC-outside

'...they should teach their children [Papapana], even though they married others from outside.'

(1-T083)

(4)

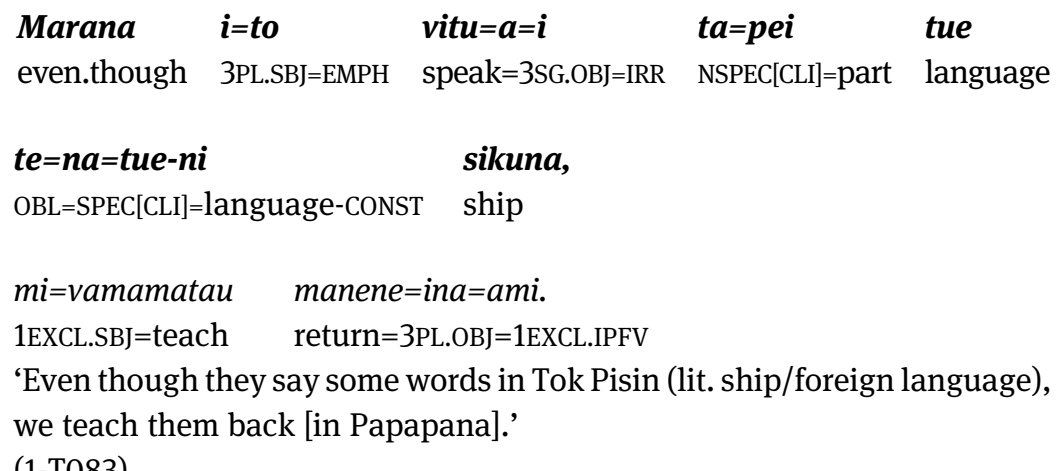

(1-T083)

\subsection{Tense, aspect and mood (TAM)}

Papapana's complex TAM system involves preverbal and/or postverbal markers and/or verbal reduplication. Most NWS languages display postverbal subjectindexing (PSI), which reflects former possessor indexing and has varying functions synchronically (see Palmer 2011: 722-723). In Papapana, PSI enclitics have a few functions but primarily express imperfective aspect.

A verb unmarked by TAM operators has past time reference, unless there are nonpast temporal adjuncts. Tense is absolute, with unmarked present but marked past tense, and future time expressed by the irrealis mood enclitic. There are five aspectual distinctions (habitual, continuous, proximative, repetitive and completive) and four mood distinctions (hypothetical conditional, counterfactual conditional, optative and apprehensive). Table 3 shows the relative positions in the VC of the TAM markers, and 


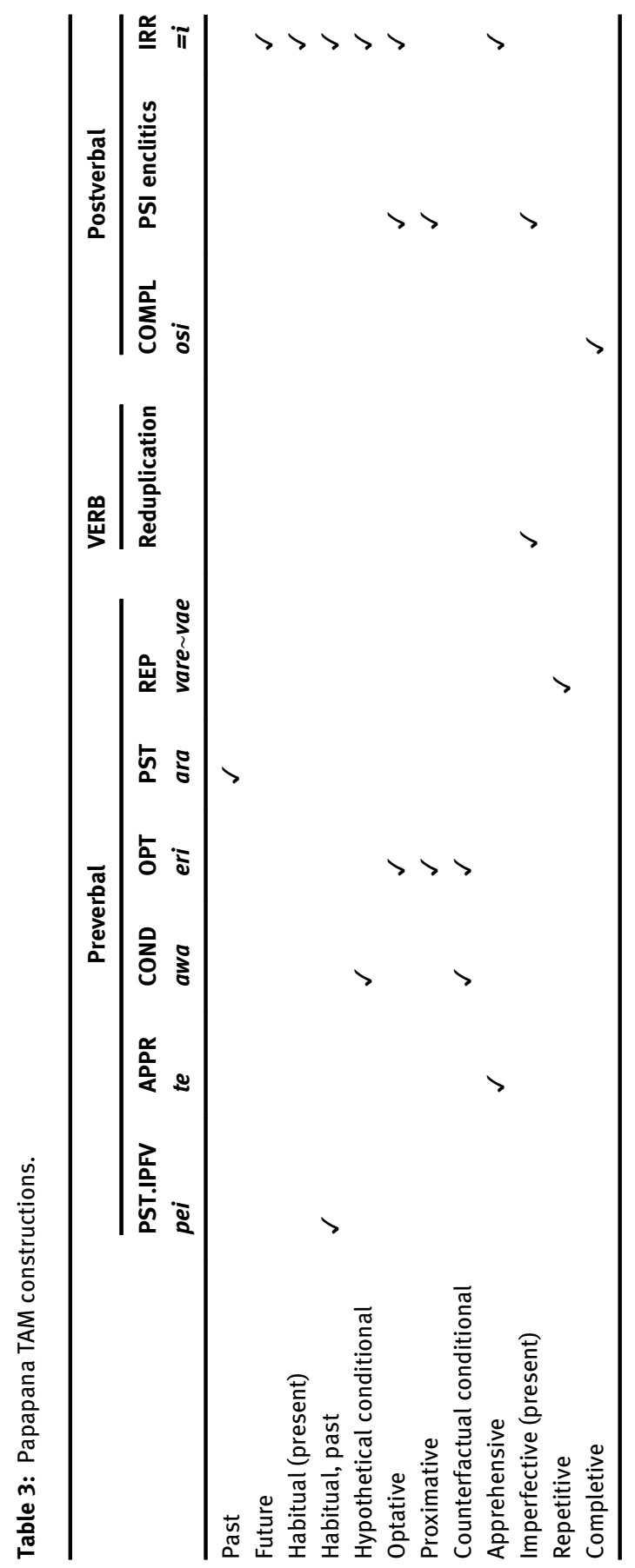


how they combine with each other and/or verbal reduplication, or how they function alone, to express the aforementioned distinctions.

\subsubsection{Irrealis mood enclitic $=i$}

Like Proto-Oceanic (POc) (see Lynch, Ross, and Crowley 2002: 84), realis mood is not morphologically marked in Papapana. Irrealis mood, which marks an event as unreal, is marked in Papapana by the postverbal enclitic $=i$.

When irrealis $=i$ is the only TAM marker, it can be used to refer to habitual events with a present time reference (5) or future events (6). Irrealis $=i$ also marks events that the speaker is hypothesising will happen (7) but without any judgement about desirability, whereas in conjunction with te in apprehension-causing clauses, the possible event is deemed undesirable (see Section 3.2).

$$
\begin{aligned}
& M i=n a o=i \quad i \text {-ava } . \\
& \text { 1EXCL.SBJ=go=IRR LOC-sea } \\
& \text { 'We (often) go to sea.' } \\
& \text { (1-T010) }
\end{aligned}
$$

$\begin{array}{lll}\text {...tue-ni Papapana } & \text { e=taosi=i } & \text { mumurina. } \\ \text { language-ATTRIB Papapana } & \text { 3SG.SBJ=finish=IRR future } \\ \text { '...Papapana language will die out in the future.' } & \\ \text { (1-T083) } & \end{array}$

$\begin{array}{lll}\text { Ben bea } \quad \text { ento }=\boldsymbol{i} & \text { te=na=au } & \text { obutu. } \\ \text { Ben maybe 3SG.SBJ=board=IRR OBL=SPEC=CLII } & \text { canoe } \\ \text { 'Maybe Ben might/will board the canoe.' }\end{array}$

(2-E007-1)

Furthermore, $=i$ can optionally be used in imperative (8) or hortative clauses, or the imperative/hortative clause carries no TAM marking whatsoever (9). Language consultants reported that not voicing $=i$ was a shorter form of expression. Crosslinguistically, "imperative clauses are likely to be irrealis, since they do not assert that X did happen” but a lack of TAM markers is also typical (Payne 1997: 247, 305). Note that since Papapana does not have inflectional morphology dedicated exclusively to imperatives and hortatives, and irrealis $=i$ is optional, imperative and hortative refer here to a clause type, not a mood distinction.

$$
\begin{array}{lll}
N u=r i s i & n u=k a k a ' i & o=d e=a=\boldsymbol{i} . \\
\text { SPEC.CLII=rope } & \text { SPEC.CLII=Small } & \text { 2SG.SBJ=take=3SG.OBJ=IRR } \\
\text { 'Take a small rope.' } & \\
\text { (1-T035) } &
\end{array}
$$




$$
\begin{aligned}
& M u=n a o, \quad m u=n o \quad \text { mai } n u=\text { daramu. } \\
& \text { 2PL.SBJ=go 2PL.SBJ=go.SEQ fetch=1SG.OBJ hither SPEC.CLII=water } \\
& \text { 'Go, go and fetch me some water.' } \\
& \text { (1-T007) }
\end{aligned}
$$

Irrealis $=i$ is also optionally used in conjunction with other verbal morphology in prohibitives (see Section 4.2) and obligatorily with past imperfective marker pei to express past tense and habitual aspect, and with the optative mood marker eri and PSI enclitics to express optative mood. In complex sentences, $=i$ operates with the conditional mood marker awa in hypothetical conditional adverbial clauses (see (2) in Section 2.1), and with apprehensive te in apprehension-causing adverbial clauses (see Section 3.2).

\subsubsection{Reduplication}

Reduplication in Papapana always involves continuous leftward copying. Reduplicants may be monosyllabic or disyllabic, and have either derivational or inflectional functions. Inflectional reduplication occurs in the VC with the reciprocal marker vei in reciprocal constructions, and with PSI enclitics to express habitual or continuous aspect. Papapana is typologically unusual, however, as some verbs also display the cross-linguistically rare phenomenon of multiple reduplication to express habitual aspect (Smith 2016c). Reduplication also occurs with preverbal negative ae or apprehensive te to negate imperatives (see Section 4.2).

\subsection{Negation}

Within the VC, negation of verbal declarative predicates (including stative predicates) is expressed by the preverbal negative marker ae (10)-(11), in both independent and subordinate clauses. Negative $a e$ is also used to negate adjectives in adjective phrases. Imperatives are negated with reduplication and either negative $a e$ or the preverbal apprehensive mood marker te (and are optionally marked by irrealis $=i$ ) (see Section 4.2). Although negated clauses are often treated as irrealis in languages that make a realis-irrealis contrast (Palmer 2001: 173-76), this is not the case in Papapana; instead mood and negation are independent and negative ae may occur in both realis (10) and irrealis (11) clauses.

$$
\begin{aligned}
& \text { Nathan e=ae ara tavotu egoego. } \\
& \text { Nathan 3SG.SBJ=NEG PST arrive well } \\
& \text { 'Nathan didn't turn out well.' } \\
& \text { (1-T104) }
\end{aligned}
$$




$$
\begin{aligned}
& I=\boldsymbol{a} \boldsymbol{\text { nongono } = \boldsymbol { i }} \text {. } \\
& \text { 3PL.SBJ=NEG hear=IRR } \\
& \text { 'They don't listen.' } \\
& \text { (1-T025) }
\end{aligned}
$$

\section{Lest it be undesirable: apprehensive clauses}

This section examines apprehensive morphemes from a typological perspective, with a focus on Oceanic and NWS languages (Section 3.1), before analysing precautioning sentences in Papapana (Section 3.2) including the syntactic status of the apprehension-causing clause (Section 3.3).

\subsection{Apprehensives}

Apprehensives convey that a situation is possible, but judged undesirable; thus, there is apprehension about the potential event. Since Dixon (1977: 349-56) first coined the term apprehensional constructions, various definitions have been proposed. Lichtenberk (1995: 295) defines apprehensives as encoding "an apprehension - typically on the part of the speaker - that a potential (undesirable) situation may turn out to be so", while Angelo and Schultze-Berndt (2016: 258) add that the state of affairs is "best avoided". Lichtenberk (1995: 291) describes apprehensional-epistemic modality as a "mixed modality" which is both epistemic and attitudinal, as it concerns "the speaker's degree of certainty about the factual status of the proposition" and their "attitude concerning the desirability of the situation".

Apprehensives have received little attention in typological and semantic literature on modality and clause linkage, despite being widespread cross-linguistically (Angelo and Schultze-Berndt 2016: 258). Vuillermet (2018: 258) suggests that one possible factor why such morphemes have been overlooked is the varied terminology: Vuillermet identifies twenty different terms including admonitive, evitative, monitory, negative purpose clauses, and timitive mood. Some accounts of apprehensive morphemes appear in grammatical descriptions of particular languages, including Australian languages such as Kayardild (kaya1319, PamaNyungan; Australia) (Evans 1995: 264-65), Amazonian languages such as Tariana (tari1256, Arawakan; Amazonia) (Aikhenvald 2003: 385-86), and Papuan and Austronesian languages (see below and Section 5). Other contributions to research on apprehensives include cross-linguistic studies (e.g. Dixon 2009: 23-25; 
Schmidtke-Bode 2009: 129-44; Verstraete 2005). Published research papers focusing specifically on apprehensive morphemes include Lichtenberk's (1995) seminal paper and, more recently, research on apprehensives in Kriol (krio1252, English-based creole; Australia) (Angelo and Schultze-Berndt 2016) and Ese Ejja (esee1248, Tacanan; Amazonia) (Vuillermet 2018).

Lichtenberk (1995) considers the 'lest' morpheme, the complementizer ada, in To'aba'ita (toab1237, Austronesian, Oceanic; Solomon Islands), and 'lest' morphemes in other languages - two Fijian varieties (fiji1243, Austronesian, Oceanic; Fiji), Hua (yaga1260, Trans-New Guinea; Papua New Guinea), Diyari (dier1241, Pama-Nyungan; Australia), Martuthunira (mart1255, Pama-Nyungan; Australia), and the Indo-European languages, Czech (czec1258), Classical Greek (anci1242), and Old English (olde1238) and Modern English (stan1293). Based on these languages, Lichtenberk delineates three functions of apprehensive markers: apprehensional-epistemic, fear, and precautioning. In the apprehensional-epistemic function, the apprehensive clause functions as an independent clause, expressing both possibility and apprehension, while in the fear function, the apprehensive clause is "embedded under a verb of fearing" (Lichtenberk 1995: 296). In the precautioning function, the apprehensive morpheme occurs in a complex sentence and encodes an "apprehension-causing” situation; such a clause is associated with a "precaution" (Lichtenberk 1995) main clause expressing preventative action which can be taken to avoid the undesirable situation. Like apprehensives in general, apprehensives with a precautioning function are not rare, as demonstrated by Schmidtke-Bode's (2009: 129-44) sample of eighty languages, of which nineteen $(23.8 \%)$ have apprehensive morphemes with a precautioning function, be it conjunctions, adverbial suffixes, postpositions, TAM markers, particles, or auxiliaries.

Lichtenberk (1995: 298) identifies two subtypes of apprehension-causing clauses: the avertive function and the 'in case' function. ${ }^{4}$ In those clauses with an avertive function, the precaution can avert the apprehension-causing event (X so that not $\mathrm{Y}$ ), or if no precaution is taken, the apprehension-causing situation will occur (if not X, then Y). In those clauses with an 'in case' function, the precaution can only avert the consequences of the apprehension-causing event, not the event itself (X in case Y). In some languages, such as Martuthunira, there is a formal distinction between avertive and 'in case' clauses (see Dench 1988: 385-86), whereas in other languages, like To'aba'ita, there is not, and the interpretation depends on "extralinguistic pragmatic factors, specifically on the presence or absence of a causal link between the two situations” (Lichtenberk 1995: 299).

4 Authors often describe apprehension-causing clauses as negative purpose clauses even though this term only covers the avertive function and not the 'in case' function. 
In the Oceanic languages mentioned so far, the apprehensive morphemes belong to different syntactic categories: $a d a$ 'lest' in To'aba'ita is a complementizer (Lichtenberk 1995); de/dē in Standard/Bauan Fijian is a subordinate verb phrase "marker" (Schütz 1985: 426); and dee in Boumaa Fijian is a "relator" which links two clauses (Dixon 1988: 258). Of the forty-three languages described in the grammar sketches in Lynch, Ross and Crowley (2002) The Oceanic Languages, eight languages (18.6\%) are reported to have an apprehensive morpheme, translated as 'lest'. ${ }^{5}$ In seven of these, the morpheme is a subordinator: Puluwatese (pulu1242, Federated States of Micronesia) (Lynch 2002c: 813), Longgu (long1395, Solomon Islands) (Hill 2002: 560), Nadrogā (west2519, Fiji) (Geraghty 2002: 836, 42, 47), Niuafo’ou (niua1240, Tonga) (Early 2002: 864), Cèmuhî (cemu1238, New Caledonia) (Lynch 2002a: 793), Xârâcùù (xara1244, New Caledonia) (Lynch, Ross, and Crowley 2002: 775), and Iaai (iaai1238, New Caledonia) (Lynch 2002b: 791). The eighth apprehensive morpheme is described as a preventative TAM particle: $o a$ 'lest' in North Marquesan (nort2845, French Polynesia) (Lynch and Ross 2002: 872). Similarly, in Mwotlap (motl1237, Vanuatu), tiple 'for fear that' is a mood (irrealis) marker (François 2003: 301-12).

Apprehensive morphemes are not mentioned in any of the five NWS language grammar sketches in Lynch, Ross and Crowley (2002): Taiof (taio1240, Bougainville, Papua New Guinea) (Ross 2002b), Banoni (piva1237, Bougainville, Papua New Guinea) (Lynch and Ross 2002), Sisiqa (sisi1250, Solomon Islands) (Ross 2002a), Kokota (koko1269, Solomon Islands) (Palmer 2002) and Roviana (rovi1238, Solomon Islands) (Corston-Oliver 2002). My review of the three published reference grammars, other (unpublished) grammar sketches and analyses, and two studies of ergativity revealed that apprehensives are not attested/reported in Kokota (Palmer 2009a), Roviana (Corston 1996), Mono-Alu (mono1273, Bougainville, Papua New Guinea) (Fagan 1986) and Nehan (neha1247, Bougainville, Papua New Guinea) (Glennon 2014; Todd 1978) but that four of these NWS languages do have apprehensive morphemes. In Ughele (ughe1237, Solomon Islands), the conjunction leke 'lest' is used in "negative purpose adverbial clauses" (Frostad 2012: 270), while in Teop (teop1238, Bougainville, Papua New Guinea), the TAM marker mene is used to express apprehensions and warnings and indicates that a situation should be avoided (Mosel and Thiesen 2007). Mene translates as 'might, lest, otherwise, or else' and can have an apprehensional-epistemic or precautioning function.

In Hoava (hoav1238, Austronesian, Oceanic; Solomon Islands), the pre-verb phrase "modal negative" maki "expresses the desire of the speaker that negative

5 I searched for all twenty terms listed in Vuillermet (2018) and variations thereof, as well as 'so that', 'in case' and 'fear'. 
consequences of an event do not occur" (Davis 2003: 247) and may have a precautioning function (12) or arguably an apprehensional-epistemic function (13). Although in (14) the subject is second person and the translation is 'don't' (and elsewhere maki is glossed as NEG.IMP), this is not a prohibitive: the speaker is not trying to make the addressee not do something (see Section 4.1), because the addressee is unlikely to intentionally hurt themselves. Instead, the speaker is warning the addressee of something (bad) that might happen.

\section{Hoava}

Taloa tu goe, maki vari-baha-e.

leave REST PRO:2SG NEG:WARN RECP-bewitch-TR:3PL

'You should leave, lest we bewitch each other.'

(Davis 2003: 255)

$\begin{array}{lll}\text { Maki } & \log a \sim \log a & \underline{\text { nina. }} \\ \text { NEG:WARN } & \text { RD lie } & \text { possibly }\end{array}$

'It's not good if you are telling fibs.'

(Davis 2003: 250)

\section{Maki ta-nani leboto. \\ NEG:WARN PASS-bite machete}

'Don't be hurt by the machete.'

(Davis 2003: 247)

In Kubokota (ghan1242, Austronesian, Oceanic; Solomon Islands), the pre-clausal adverb keta is glossed as 'lest' and is "used to warn of negative consequences if an event should take place” (Chambers 2009: 147). Keta has a 'fear' function, an apprehensional-epistemic function (15) and a precautioning function (16), and the clause it marks is usually in the prospective irrealis mood (Chambers 2009: 147). In some examples, such as (15), the translation is 'not' or 'don't let him/her...' and (15) even has a second person subject. However, like Hoava example (14), this is not a prohibitive.

\section{Kubokota}

(15) Keta mu lotu ko mu paleka. lest 2.IRR fall so 2.IRR wound

'Be careful not to fall and hurt yourself.'

(Chambers 2009: 147)

$$
\begin{array}{lllllll}
\text { Lao } & \text { teku=a, } & \text { keta } & \text { mi } & \text { iqolo } & \text { soga=i } & \text { maka! } \\
\text { go } & \text { take=3SG.OBJ } & \text { lest } & \text { 3SG.IRR } & \text { wake } & \text { again=3SG.OBJ } & \text { one }
\end{array}
$$
'Go and get [the crying child], so she doesn't wake up the other one!' (Chambers 2009: 89) 
The research suggests that in Oceanic and NWS languages, apprehensive morphemes tend to be subordinators and have at least a precautioning function. As Section 3.2 shows, the apprehensive morpheme in Papapana has a precautioning function and is not a subordinator but a preverbal mood marker inside the VC.

\subsection{Papapana apprehensives}

In Papapana, the preverbal apprehensive mood marker te co-occurs with irrealis $=i$. Te occurs inside the VC in Papapana after subject-indexing proclitics but before the verb (see Tables 1 and 2) and is therefore not a subordinator, as subordinators are external to the VC; see (3)-(4) in Section 2.1. Te does not co-occur with any other TAM markers, nor with negative $a e$, nor is it attested with the emphatic marker to, therefore the subject proclitics always attach to te.

In both elicitation and text data, apprehensive te and irrealis $=i$ are used in the apprehension-causing adverbial clause of a precautioning sentence, while the precaution main clause may be imperative (17)-(18), hortative (19) or prohibitive (20). There is only one example in the corpus of a declarative main clause (21). The precaution clause in Papapana usually has a second person subject but can have a first or third person subject as in (19) and (21). The apprehension-causing clause can have a second person subject as in (17) or third person subject as in the remaining examples, but there are no examples in the corpus of a first person subject. Thus, unlike the results of Schmidtke-Bode's (2009: 133) typological study, there is no preference in Papapana for non-co-referential subjects.

$$
\begin{array}{lll}
O=\text { nabe }=\boldsymbol{i}, & \boldsymbol{o}=\boldsymbol{t} \boldsymbol{e} & \text { mate }=\boldsymbol{i} . \\
\text { 2SG.SBJ=swim=IRR } & \text { 2SG.SBJ=APPR } & \text { die=IRR }
\end{array}
$$

'Swim, (otherwise) you might die.'/ 'Swim, (so that) you don't die.'

(2-E028-2)

$\begin{array}{llllll}\text { Ta } & \text { na=au } & \text { dada } & \text { o=noe } & \text { a'aisi, } & \text { e=te } \\ \text { but } & \text { SPEC=CLII } & \text { coconut.milk } & \text { 2SG.SBJ=put } & \text { many } & \text { 3SG.SBJ=APPR }\end{array}$

tuatuare $=\boldsymbol{i}$.

burn=IRR

'But put lots of coconut milk [on your hands], (otherwise) it will burn.'/ 'But put lots of coconut milk [on your hands], (so that) it doesn't burn.' (1-T036-8)

\begin{tabular}{|c|c|c|c|c|}
\hline$" S \boldsymbol{a}=$ nao & tovoni & $n a o=\boldsymbol{i}$ & $i=t e$ & moroko=ira $=\mathbf{i} . "$ \\
\hline 1INCL.SBJ.HORT=go & check & thither=IRR & 3PL.SBJ=APPR & lie $=1 \mathrm{INCL} . \mathrm{OBJ}=\mathrm{IRR}$ \\
\hline
\end{tabular}




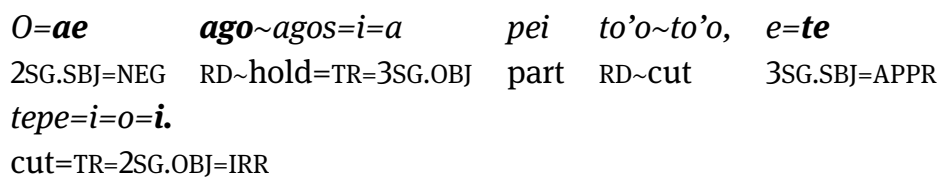

The position of the two clauses is fixed: the main clause precedes the adverbial clause. This is a common cross-linguistic tendency (Dixon 2009: 48) and is iconic since the precaution clause has directive illocutionary force, aiming to prevent the potential, undesirable event in the apprehension-causing clause from occurring.

There is no formal distinction between avertive and 'in case' clauses in Papapana, as demonstrated clearly in (22) and (23), and the interpretation depends on the presence or absence of a causal link between the two situations. The Papapana utterances presented above can generally be interpreted as avertive, though (19) can only be interpreted as 'in case'. In (19), the speaker is recounting when the army distributed papers announcing a ceasefire during the Bougainville Crisis. The speaker, or his companion, uttered (19), suggesting that they check if the army were lying. They could not prevent the army lying, but the precaution of verifying the message could avert the consequences of the potential lie.

$$
\begin{aligned}
& \mathrm{Nu}=\text { ta } \sim \text { taguvu } \quad \mathrm{o}=\mathrm{de}=\mathrm{a}, \mathrm{te} \quad \text { u'usi }=\mathrm{i} \text {. } \\
& \text { SPEC.CLII=RD cover 2SG.OBJ=take=3SG.OBJ 2SG.SBJ=APPR wet=IRR }
\end{aligned}
$$

'Take the umbrella, (otherwise) you might get wet.'/'Take the umbrella, (so that) you don't get wet.'

(3-E002)

$$
\begin{array}{llll}
O=d e=a & n u=t a \sim \text { taguvu, } & \text { na=naoi } & \boldsymbol{e}=\boldsymbol{t} \boldsymbol{e} \\
\text { 2SG.OBJ=take=3SG.OBJ } & \text { SPEC.CLII=RD cover } & \text { SPEC[CLI]=rain } & \text { 3SG.SBJ=APPR } \\
\text { si' } \boldsymbol{i}=\boldsymbol{i} . & & \\
\text { rain=IRR } & &
\end{array}
$$

'Take the umbrella, (in case) it might rain.'

(3-E002) 


\subsection{Papapana: the syntactic status of the apprehension- causing clause}

One of the main issues in the existing literature on apprehensives is their syntactic and/or pragmatic status as dependent or independent clauses. In Papapana, the apprehension-causing clause is pragmatically dependent, since it justifies the precaution expressed in the main clause, as François (2003: 308) also argues for the 'Évitatif' tiple 'for fear that' in Mwotlap. I also consider the Papapana apprehension-causing clause to be syntactically dependent, for the following reasons. Firstly, apprehension-causing clauses meet criterion (ii) for defining adverbial clauses as subordinate (Section 2.1) because there is no strong evidence that apprehensive te together with irrealis $=i$ can occur in independent apprehensive clauses (Section 3.3.1). A subordinator can also be employed (Section 3.3.2), in which case, apprehension-causing clauses additionally meet criteria (iii). Furthermore, in most examples of Papapana precautioning sentences, the speaker judges the event possible and undesirable, and directs the addressee to take a precaution to avoid this event. However, in (21) it is the female subject who judges the event to be possible and undesirable and it is she who takes a precaution. In Ese Ejja, this difference in perspective (speaker vs. subject) is "a key element to understanding how the Apprehensive [a main clause mood marker] and the Avertive [a subordinate clause marker] semantically relate to one another" (Vuillermet 2018: 280). Using this criterion would also identify Papapana apprehensioncausing clauses as subordinate since the evaluator of the undesirability is the subject of the main clause (which may or may not be the speaker).

\subsubsection{Apprehension-causing clause as a dependent clause}

There is no strong evidence that the combination of apprehensive te and irrealis $=i$ (with a non-reduplicated verb), occurs in independent clauses with an 'apprehensional-epistemic' function. The only examples where a clause marked by te and $=i$ does occur independently come from one language consultant during elicitation sessions in April 2018 and only when (i) we'd discussed the complex sentence first such as in (24) which corresponds to (17), (ii) when I provided context such as a shocked facial expression or I'd uttered Tok Pisin lukaut 'look out' (25), or (iii) when I elicited with Tok Pisin nogut 'lest' (26).

(24) $O=$ te mate $=$.

2SG.SBJ=APPR die=IRR

'You might die.'

(3-E002) 


$$
\begin{aligned}
& \mathrm{Na}=\text { 'oru } \quad \text { ete } \quad \text { ani }=\mathrm{O}=\boldsymbol{i} \text {. } \\
& \text { SPEC[CLI }]=\text { snake } 3 \text { SG.SBJ=APPR eat }=2 \mathrm{SG} . \mathrm{OBJ}=\mathrm{IRR}
\end{aligned}
$$

'The snake might/will bite you.'

(3-E002)

$\begin{array}{llll}U=t \boldsymbol{e} & \text { nao }=\boldsymbol{i} & \text { Buka } & \text { natui. } \\ \text { 1SG.SBJ=APPR } & \text { go=IRR } & \text { Buka } & \text { tomorrow }\end{array}$

'Nogut bai mi go long Buka tumora [I might go to Buka tomorrow].'

(3-E002)

The consultant was arguably biased in (26) by Tok Pisin, especially as when I elicited using English might, the utterance produced involved irrealis $=i$ and bea 'maybe' as in (27) (and also in (7) in Section 2.2.1).

$\begin{array}{llll}\text { Anau bea kaukau } \quad u=a n i=i & i \text {-boni. } \\ \text { 1SG maybe sweet.potato 1SG.SBJ=eat=IRR } & \text { LOC-night } \\ \text { 'I might eat sweet potatoes tonight.' } & \end{array}$

(3-E002)

For the other instances of $t e$ and $=i$ in isolated clauses, the consultant arguably had the precaution clause in mind, either because we'd discussed the complex sentence then I had asked about the acceptability of $t e$ and $=i$ in an independent clause, or because I provided context. The apprehension-causing clause is thus arguably not independent because there is an implicit precaution clause. Indeed, François (2003: 310-11) also considers a few cases of isolated 'Évitatif' clauses in Mwotlap and argues that this independence is due to an implicit precaution. Sometimes in the Mwotlap examples, the precaution clause may be restored/ implied from the context; for example, the speaker might utter the vocative ohoo! 'no!' and then justify this refusal with an apprehension-causing clause. On other occasions, the semantic content of the precaution clause is inferable from the addressee's actions, which the speaker reacts to before uttering their apprehension. Similarly, in Diyari, subordinate 'lest' clauses, marked by the verbal suffix -yati, are occasionally found "where there appears to be no main clause to which they are subordinated" (Austin 1981: 225), but "it is clear from the context that an 'understood' imperative, warning, or suggestion is implicit" and such clauses "may be regarded as structurally subordinate because it is always possible to add a main clause before them" (Austin 1981: 229, original emphasis). Evans (2007) however regards such clauses as insubordinated independent clauses (see Section 6.2.3). 
Examples (24)-(27) are not considered strong evidence that te and $=i$ (with a non-reduplicated verb) can occur in independent clauses because they arise from one day's elicitation with one consultant, who was arguably influenced by the discussion, context or elicitation language. More importantly, there is no supporting evidence from the text data of independent clauses being marked by te and $=i$, nor from any elicitation data collected between 2011 and 2013.

\subsubsection{Use of a subordinator}

In Papapana, the apprehension-causing clause is not usually introduced by a subordinator, however, the subordinator tenava 'so that' (as in (21) above) or the general subordinator avosia can be employed:

(28) O=tavia o'ogo $=a=i$, avosia saviako te ani o na=gono, 2SG.SBJ=rub well=3SG.OBJ=IRR SUBR tapioca OBL 2SG or SPEC[CLI]=banana mata $=$ au $o=$ to atuma'as $=\mathrm{i}=\mathrm{a}=\mathrm{i}, \quad$ e $=$ te ravarava $=\mathrm{i}$ what=CLII 2 SG.SBJ=EMPH $\quad$ cook=TR=3SG.OBJ=IRR $3 \mathrm{SG} . \mathrm{SBJ}=\mathrm{APPR} \quad$ black=IRR

$\begin{array}{lll}o=\text { to } & \text { eri } & \text { tatu }=\text { in } a=m u=i . \\ \text { 2SG.SBJ=EMPH } & \text { OPT } & \text { mash=3PL.OBJ=2SG.IPFV=IRR }\end{array}$

'You rub it well, so that your tapioca or the banana, whatever you cooked, won't be black when you want to mash them.'

(1-T036-8)

The subordinators tenava 'so that' (29)-(30) and avosia (31) also introduce finite positive purposive adverbial clauses where the subjects of the adverbial and main clause are non-coreferential. These subordinators do not occur in independent clauses, and the subordinate clause may precede (29) or follow (30)-(31) the main clause.

(29) Tenava na='usia $i=a p u t u=i$,

so.that $\quad$ SPEC[CLI $]=$ child $\quad 3 P L . S B J=S l e e p=I R R$

iai pei ena mama $i=a t u=a=i$.

PROX PART sing DEM1 3PL.SBJ=make=3SG.OBJ=IRR

'So that the children will sleep, they sing this little song.' (1-T048) 


$$
\begin{array}{ll}
I=n o & u v u=i \\
\text { 3PL.SBJ=go.SEQ } & \text { clear=IRR }
\end{array}
$$

$\begin{array}{lll}\text { tenava } & e \text {-sina-na } & e=\operatorname{siod}=i=a=i \\ \text { so.that } & \text { PERS-mother-3SG.PSSR } & \text { 3SG.SBJ=Work=TR=3SG.OBJ=IRR }\end{array}$

na=uvu.

SPEC[CLI $]=$ clear

'They cleared grass so that his mother could work the clearing.'

(1-T027-2)

\begin{tabular}{|c|c|c|c|}
\hline Anau & \multicolumn{3}{|l|}{$u=$ vagasi $i=a$} \\
\hline $1 S G$ & 1SG.SBJ=faster & $=3 \mathrm{SG} . \mathrm{OBJ}$ & $\mathrm{I}=\operatorname{dog}$ \\
\hline avosia & $e=a e$ & $a m u=i n a=i$ & na=vanu $a$. \\
\hline SUBR & 3SG.SBJ=NEG & bite $=3$ PL.OBJ $=I R R$ & SPEC $[$ CLI $]=$ people \\
\hline
\end{tabular}

(31)

\section{Don't feel obligated: prohibitive clauses}

This section describes prohibitives from a typological perspective, with a focus on Oceanic and NWS languages (Section 4.1), before analysing prohibitive constructions in Papapana (Section 4.2) including the difference between the use of negative $a e$ and apprehensive te (Section 4.3).

\subsection{Prohibitives}

Prohibitives, also called negative imperatives, are constructions in which "the speaker tries to make the hearer not realize some state of affairs" (Devos and Van Olmen 2013: 22). Cross-linguistically, in a sample of 495 languages, van der Auwera and Lejeune (2013) identify four strategies for forming prohibitives: (i) a positive imperative verbal construction combined with the declarative negative strategy (23\%); (ii) a positive imperative verbal construction combined with a negative strategy not found in declaratives (37\%); (iii) a verbal construction other than the positive imperative, and the declarative negative strategy (11\%); (iv) a verbal construction other than the positive imperative and a negative strategy not found in declaratives (29\%). 
In Oceanic languages, prohibitions "usually display a different form of negation from declaratives" (Lynch, Ross, and Crowley 2002: 52). Indeed, in a collaborative study of negation in Oceanic languages, Mosel (1999: 15) reports that, except the Loyalty Islands languages, "all the languages in our sample formally distinguish the negation of assertive and imperative clauses". ${ }^{6}$ This aligns with van der Auwera and Lejeune's (2013) findings where 66\% of the languages in their sample use a distinct negator in prohibitives. Nevertheless, out of 37 sketch grammars in Lynch, Ross and Crowley (2002) which describe prohibitives, $27 \%$ of languages use the same negator in both declaratives and imperatives. In terms of the verbal construction, $70 \%$ of the 37 languages use the same verbal construction as the imperative, while $25 \%$ use a different verbal construction. This again aligns with van der Auwera and Lejeune's (2013) findings where $60 \%$ of the languages in their sample use the same verbal construction as the imperative.

Among the NWS languages for which I could find descriptions of prohibitives, Nehan (Todd 1978), Hoava (Davis 2003), Kokota (Palmer 2002), Kubokota (Chambers 2009) and Ughele (Frostad 2012) all use the same negator in both declaratives and imperatives, while Banoni (Lynch and Ross 2002), Sisiqa (Ross 2002a) and Taiof (Ross 2002b) use distinct negators. Furthermore, Hoava, Kokota and Kubokota all use the same verbal construction as the imperative, while Banoni, Ughele and Sisiqa use a different verbal construction for the prohibitive. Among these eight languages, it is therefore more common to use the same negator, and the imperative verbal construction: the former does not align with van der Auwera and Lejeune's (2013) findings, whereas the latter does. As Section 4.2 shows, Papapana uses two of the four prohibitive strategies identified in van der Auwera and Lejeune (2013): (iii) the use of a distinct verbal construction and the declarative negative strategy and (iv) the use of a distinct verbal construction and a distinct negative strategy.

\subsection{Papapana prohibitives}

As Table 4 shows, Papapana prohibitives are formed with monosyllabic or disyllabic verbal reduplication, sometimes irrealis $=i$, and then either preverbal negative ae as in (32)-(33), which also negates verbal declarative predicates and adjectives (Section 2.3), or preverbal apprehensive te as in (34)-(35). I use the term

\footnotetext{
6 This sample includes in-depth studies on negation in seven Oceanic languages from four different subfamilies, and a survey of negation in the New Caledonian and Loyalty Island languages.
} 
prohibitive, rather than negative imperative, because these clauses are not simply negated imperative clauses, as positive imperative clauses do not have a reduplicated verb (compare (34) with munao 'go' in (9) in Section 2.2.1). As with imperative and hortative clauses (Section 2.2.1), irrealis = $i$ may be present as in (32) and (34), or absent as in (33) and (35). Like imperative and hortative clauses, the absence of $=i$ in prohibitives is considered to be ellipsis in casual speech.

Table 4: Papapana imperative and prohibitive constructions.

\begin{tabular}{lllll}
\hline & $\begin{array}{l}\text { APPR } \\
\text { te }\end{array}$ & $\begin{array}{l}\text { NEG } \\
\boldsymbol{a e}\end{array}$ & $\begin{array}{l}\text { Verb } \\
\text { reduplication }\end{array}$ & $\begin{array}{l}\text { IRR } \\
=i\end{array}$ \\
\hline Imperative/Hortative & & & & $(\checkmark)$ \\
Prohibitive 1 & $\checkmark$ & $\checkmark$ & $(\checkmark)$ \\
Prohibitive 2 & $\checkmark$ & & $\checkmark$ & $(\checkmark)$ \\
\hline
\end{tabular}

$$
\begin{array}{ll}
M u=a \boldsymbol{e} & \boldsymbol{v a} \sim \text { vatan }=\boldsymbol{i}=\boldsymbol{a}=\boldsymbol{i} . \\
\text { 2PL.SBJ=NEG } & \mathrm{RD} \sim \text { tell }=\mathrm{TR}=3 \mathrm{SG} . \mathrm{OBJ}=\mathrm{IRR}
\end{array}
$$

'Don't tell him.'

(1-T065)

$\begin{array}{llll}O=a \boldsymbol{e} & \text { oto } \sim \text { oto } & \text { te }=n a=a u & \text { obutu } \\ \text { 2SG.SBJ=NEG } & \mathrm{RD} \sim \text { board } & \mathrm{OBL}=\mathrm{SPEC}=\mathrm{CLII} & \text { canoe } \\ \text { 'Don't board the canoe.' } & & \end{array}$

(2-E026)

$$
\begin{array}{ll}
\text { “Mu=te } & \text { nao } \sim \text { nao }=\boldsymbol{i} . " \\
\text { 2PL.SBJ=APPR } & \mathrm{RD} \sim \mathrm{go}=\mathrm{IRR} \\
\text { "“Don't go.” } &
\end{array}
$$$$
\text { (1-T053) }
$$

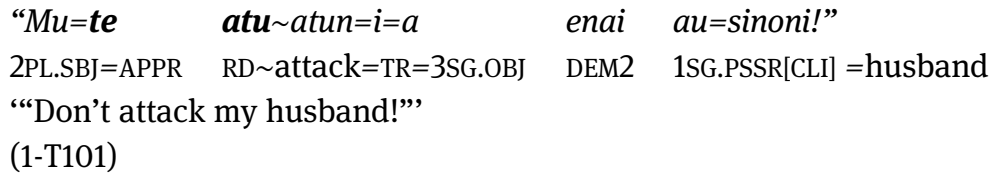

Verbal reduplication in prohibitives may be monosyllabic or disyllabic but it is unclear what motivates the type of reduplication (see Smith 2016c: 541). Papapana verbal reduplication principally expresses augmentation of events (continuous, 
habitual, and reciprocal) (Smith 2016c), a typical semantic property expressed by reduplication cross-linguistically (Kajitani 2005); however, the use of verbal reduplication in prohibitives is more unusual and less iconic. Nevertheless, verbal reduplication in negative clauses is attested in NWS languages: it occurs in prohibitives in Banoni (Lynch and Ross 2002: 450), and in Torau verbal reduplication is obligatory when negation is expressed by the suffix - $k a$ on the preverbal modal/ subject-indexing particle (Palmer 2009b).

\subsection{Papapana: negative ae versus apprehensive te}

While verbal reduplication and optional use of irrealis $=i$ are characteristic of all Papapana prohibitives, some prohibitive clauses employ preverbal negative ae (which also negates verbal declarative predicates and adjectives), while others utilise preverbal apprehensive te. The use of $a e$ is two times more frequent than te in my text corpus.

During my 2011-2013 fieldwork, consultants could not account for the difference between ae and te; these markers were deemed interchangeable as shown in (36) and (37).
a. $O=$ ae to $\sim$ tonu, $o=t e \quad p u=i$.
2SG.SBJ=NEG RD Stand 2SG.SBJ=APPR fall=IRR
'Don't stand up, (otherwise/in case) you might fall.'
(2-E028-2)
b. $O=$ te $\quad$ tonu, $o=t e \quad p u=i$.
2SG.SBJ=APPR $\quad \mathrm{RD} \sim \mathrm{Stand} \quad 2 \mathrm{SG} . \mathrm{SBJ}=\mathrm{APPR} \quad$ fall $=\mathrm{IRR}$
'Don't stand up, (otherwise/in case) you might fall.'
(2-E028-2)
a. $O=a e$
ago $\sim \operatorname{agos}=i=a$
pei to'o to'o.
2SG.SBJ=NEG
$\mathrm{RD} \sim \mathrm{hold}=\mathrm{TR}=3 \mathrm{SG} . \mathrm{OBJ}$
PART RD Cut
'Don't hold the knife.'
(2-E026)
b. $O=$ te ago $\sim$ agos $=i=a$ pei to'o to'o.
2SG.SBJ=APPR RD hold=TR=3SG.OBJ PART RD Cut
'Don't hold the knife.'
(2-E026)


However, in 2018, one consultant ${ }^{7}$ suggested that ae is used when prohibiting someone from doing something they have not done yet (38a), while te is used when prohibiting someone from doing something they have already commenced (38b). Similarly for (37a), the consultant said that the addressee is not holding the knife yet, while in (37b) they are already holding it.

$$
\begin{aligned}
& \text { a. } O=a \text { vae } \sim \text { vaene, } o=t e \quad p u=i \text {. } \\
& \text { 2SG.SBJ=NEG RD climb 2SG.SBJ=APPR fall=IRR } \\
& \text { 'Don't climb [that tree], (otherwise) you might fall.' } \\
& \text { (3-E001) } \\
& \text { b. } O=\text { te vae vaene, } o=t e \quad p u=i \text {. } \\
& \text { 2SG.SBJ=APPR } \quad \mathrm{RD} \sim \text { climb } \quad \text { 2SG.SBJ=APPR fall=IRR } \\
& \text { 'Stop climbing [that tree], (otherwise) you might fall.' } \\
& \text { (3-E001) }
\end{aligned}
$$

The analysis of the difference between $a e$ and te is supported by two traditional narratives. In (39) people are running with bows and clubs to attack a woman's 'bird husband' and she suddenly jumps down and exclaims (39). In (40) a frog meets a wallaby, who is crying because his friends have been killed. The wallaby says he is sad and the frog tells him not to be. In both narratives, the situation is already underway when the prohibition is given.

$\begin{array}{llll}\text { “Mu=te } \quad \boldsymbol{a t u} \sim a t u n=i=a & \text { enai } & \text { au=sinoni!” } \\ \text { 2PL.SBJ=APPR } \quad \mathrm{RD} \sim \text { attack=TR=3SG.OBJ } & \text { DEM2 } & \text { 1SG.PSSR[CLI]=husband } \\ \text { "“Don't attack my husband!” } & & \\ \text { (1-T101) } & & \end{array}$

7 This consultant was no more proficient in Papapana than the consultants in elicitation sessions 2-E026 and 2-E028, nor was her proposed distinction age-related, since she was in her early forties in 2018, whereas the other consultants were in their sixties, or late thirties/ early forties. The consultant in 3-E001 and 3-E002 grew up speaking Papapana and Rotokas; however, language contact is unlikely as an influencing factor in her analysis since multilingualism is pervasive in the community, and in fact her Papapana-speaking mother was one of the consultants in 2-E028. Instead it is likely that the consultant in 3-E001 and 3-E002 was able to account for a difference between $a e$ and $t e$ because she is attuned to the meanings of lexemes and grammatical features, which is facilitated by her good command of English and her knowledge of grammatical terminology (partly acquired in her profession as a teacher). 


$$
\begin{array}{lll}
\text { “O=te } & \text { nami } \sim \text { nami } & \text { dua }=\text { mu }=\boldsymbol{i} . " \\
\text { 2SG.SBJ=APPR } & \mathrm{RD} \sim \mathrm{sad} & \mathrm{bad}=2 \mathrm{SG} . \mathrm{IPFV}=\mathrm{IRR}
\end{array}
$$

“"Don't feel sad."”

In three other narratives, it is unclear whether the action has commenced or not because the narrator does not provide enough detail. For example, in 1-T012, an old woman tells a boy not to pick a coconut (41), but he can pick it when he goes home. Later, as he is leaving, she asks if he is going to pick the coconut and tells him not to knock it down (42). It could be that the boy has made a move towards picking the coconut and (41) is intended to stop him, while in (42) he has started to knock the coconut down and is told not to. If so, the analysis of the difference between ae and te would be supported.

$$
\begin{aligned}
& \text { "Mama o=te pu } \sim p u s=i=a=m u=i \text {." } \\
& \text { DEM1 2SG.SBJ=APPR RD break. off }=\mathrm{TR}=3 \mathrm{SG} . \mathrm{OBJ}=2 \mathrm{SG} . \mathrm{IPFV}=\mathrm{IRR} \\
& \text { “"Don't pick that (coconut)."' } \\
& \text { (1-T012) }
\end{aligned}
$$

$$
\begin{aligned}
& \text { “ } O=\text { te } \quad v a \sim v a-p u=i=a=m u=i, \\
& \text { 2SG.SBJ=APPR RD CAUS-fall }=\mathrm{TR}=3 \mathrm{SG} . \mathrm{OBJ}=2 \mathrm{SG} . \mathrm{IPFV}=\mathrm{IRR} \\
& o=m e-a \quad \text { ovu dini mai." } \\
& \text { 2SG.SBJ=COM-SG.OBJ climb down hither } \\
& \text { “"Don't knock it down (lit. make it fall), climb down here with it.”, } \\
& \text { (1-T012) }
\end{aligned}
$$

Nevertheless, in a Bougainville Crisis narrative, it could be argued that this analysis of ae and te is supported, or not. In 1-T053, the speaker recounts how she and other women were travelling up into the bush and were stopped by soldiers who asked where they were going. The women answered that they were going to see women up in the bush, to which the soldiers responded (43). The speaker describes how they were lined up and had guns and knives pointed at their mouths and then told (44). When the women clarified that they were not looking for someone else, but were going to see some women, the soldiers uttered (45).

8 It is unclear why PSI enclitics are used in (40)-(42). In conditional clauses and in imperatives, we find PSI enclitics when the verb is po 'stay, exist' but in prohibitives, PSI enclitics occur with other verbs as well. Their use is not dependent on valency nor the verb's semantic class, nor is it speaker-related. It could reflect more widespread use of PSI diachronically. Further research is required to solve this matter. 


$$
\begin{array}{lll}
\text { “Mu=tonu, } & m u=\boldsymbol{a} \boldsymbol{n} & \boldsymbol{n a o} \sim \text { nao }=\boldsymbol{i} . " \\
\text { 2PL.SBJ=stand } & \text { 2PL.SBJ=NEG } & \text { RD } \sim \text { go }=\mathrm{IRR}
\end{array}
$$

“"Stand, don't go.",

(1-T053)

$\begin{array}{lllll}\text { “Mu=ae } & \text { nao } \sim \text { nao } & \text { tae, } & \text { mu=ae } & \text { nao nao=i.” } \\ \text { 2PL.SBJ=NEG } & \text { RD go } \quad \text { up } & \text { 2PL.SBJ=NEG } & \text { RD go=IRR } \\ \text { '“Don't go up, don't go.” } & & \\ \text { (1-T053) }\end{array}$

$$
\begin{array}{ll}
\text { “Mu=te } & \text { nao } \sim \text { no }=\boldsymbol{i} . ” \\
\text { 2PL.SBJ=APPR } & \text { RD } \sim \mathrm{go}=\mathrm{IRR} \\
\text { “'Don’t go.", } & \\
\text { (1-T053) } &
\end{array}
$$

Since both ae and te are used in the same context (and the women had made no further progress with their journey), this supports the idea that there is no semantic distinction between ae and te. Alternatively, it could be that once the soldiers discovered/believed the women's intentions, they perceived their journey as already in progress and were instructing them to cease it. If so, the recently proposed analysis is supported. Otherwise, it might be that prohibitives with ae are used for general prohibitions, whether the action has commenced or not, whereas prohibitives with te are restricted to contexts where the action has begun and thus the prohibition has more urgency and/or warns of undesirable consequences. Thus in 1-T053, ae is used to prohibit movement that has commenced, then te is used to prohibit movement that has commenced, but there is more urgency and/or a warning.

Whichever analysis of the ae and te distinction is most accurate, it is more likely that there is a difference in meaning between ae and te; after all, true synonyms are very rare. Similar to Papapana, there is a distinction between immediate and delayed future forms in imperatives in a number of languages (Aikhenvald 2010: 182-83). For example, Nambiquara (sout2944, Nambikwaran; Brazil) has a "cessation" imperative which denotes 'stop immediately', whereas there is no urgency for the prohibitive 'don't' (Kroeker 2001: 30-32). The only other Oceanic language that I have encountered which has two prohibitive morphemes like Papapana is Ulithian (ulit1238, Federated States of Micronesia), which has preverbal towee 'future negative', glossed as NEG:IMP, and preverbal ðe 'mild negative imperative' (Lynch 2002d). Meanwhile in Banoni, a 'shouldn't' interpretation can be achieved with irrealis $m a$ and the usual negator to and this contrasts with a distinct negator and verbal reduplication for prohibitives 
(Lynch and Ross 2002). The difference between Papapana ae and te will be returned to in Section 6.2.2.

\section{Cross-linguistic apprehensive and prohibitive similarity}

This section investigates languages where an apprehensive and prohibitive morpheme are formally similar/identical, exploring the relationship between these two meanings, which is often arguably one of polysemy, that is, "multiple senses of the same phonological word" which "are judged to be related" (Saeed 2016: 60). Section 5.1 focuses on non-Austronesian languages, Section 5.2 on Austronesian languages including Oceanic languages, while Section 5.3 examines the relationship between the use of te in apprehension-causing and prohibitive clauses in Papapana.

\subsection{Non-Austronesian languages}

Pakendorf and Schalley (2007) find the use of affirmative forms to express prohibitives rare: only six languages (3.7\%) in their typological sample of 163 languages use an affirmative form to express prohibition, and it is only in two of these, Sakha (yaku1245, Turkic; Russian Federation) and Lavukaleve (lavu1241, Papuan isolate; Solomon Islands), where there is cross-over between apprehensive and prohibitive forms.

In Sakha, there are two imperative paradigms, an Immediate Future Imperative and a Distant Future Imperative, with prohibitives being regularly derived from imperatives with a negative suffix (Pakendorf and Schalley 2007: 517-18). However, Sakha also has a Voluntative-Potential paradigm, expressing possibility and hope, and occasionally having "an apprehensive nuance” (Pakendorf and Schalley 2007: 518), and it is the second person affirmative Voluntative-Potential form which can also be used to convey future prohibition.

In Lavukaleve, the admonitive mood suffix $-n$ has several meanings: admonitive, deleterious possibility, negative imperative, irrealis and exhortative (Terrill 2003: 335-39). The admonitive usage warns against something, "telling the hearer to avoid something bad", which sometimes contains an implied prohibition (Terrill 2003: 335). The deleterious possibility usage indicates "that something bad might happen, without any implied command” (Terrill 2003: 335) and could thus be termed apprehensive. The admonitive mood suffix $-n$ can also be used in a 
negative imperative where it tells the hearer not to do something, but there is "no implication that bad results will follow if the hearer ignores the command" (Terrill 2003: 336). Unlike Sakha, Lavukaleve does not have other negative forms which can prohibit an action (Pakendorf and Schalley 2007: 520).

Another Papuan language where an apprehensive morpheme also has a prohibitive meaning is Rotokas, with which Papapana speakers are in contact (Section 1). In Rotokas, the particle teapi 'lest' has an "apprehensional” function and is used "to conjoin a clause that describes an undesirable situation" (Robinson 2011: 144). Teapi can be used in independent apprehensive clauses, following the predicate 'to be afraid', or in an apprehension-causing clause with either an avertive function (46) or 'in case' function. However, teapi is also glossed as PROH and translated as 'don't' (47), 'you can't' or 'you mustn't'. There is another prohibitive construction involving opeita 'PROH, don't', a distinct negator, not used to negate declarative clauses (like Papapana ae is). Robinson (2011) does not describe the formation of prohibitives that use teapi and opeita.

\section{Rotokas}

\begin{tabular}{|c|c|c|c|c|}
\hline $\begin{array}{l}\text { Avuki-vira } \\
\text { secure-ADV }\end{array}$ & $\begin{array}{l}\text { monia } \\
\text { money }\end{array}$ & $\begin{array}{l}\text { tovo- } a-v o \\
\text { put-1SG } \beta-\mathrm{IP} \beta\end{array}$ & $\begin{array}{l}\text { benk }=i a \\
\text { bank=LOC }\end{array}$ & $\begin{array}{l}\text { teapi } \\
\text { lest }\end{array}$ \\
\hline$v a$ & & iru-i-ve. & & \\
\hline PPRO.3.SG.N & & l-3PL $\beta-S B J V^{9}$ & & \\
\hline
\end{tabular}

'I am putting money in the bank so that they don't steal it.'

(Robinson 2011: 144)

\begin{tabular}{|c|c|c|c|c|}
\hline Teapi & ragai $=v a$ & voroko-pa-u & osia & $v \ddot{i}=r e$ \\
\hline PROH & PPRO.1.SG $=\mathrm{ABL}$ & arrogant-CONT-2SG $\alpha$ & as & PPRO.2.SG=ALL \\
\hline \multicolumn{5}{|c|}{ reoreo-pa-ra. } \\
\hline \multicolumn{5}{|c|}{ talk-CONT-1SG $\alpha$} \\
\hline $\begin{array}{l}\text { 'Don't } \\
\text { (Robin }\end{array}$ & $\begin{array}{l}\text { arrogant with } \\
\text { n 2011: } 164 \text { ) }\end{array}$ & e as I'm talking to & & \\
\hline
\end{tabular}

In Tok Pisin, to which Papapana speakers are shifting (Section 1), nogut denotes 'lest, don't, else, otherwise' (Baing et al. 2008: 56) and can be used for a warning (48) or a prohibition (49). Prohibition can also be expressed using no ken 'cannot, may not, don't' (Baing et al. 2008: 56; 188). Aikhenvald (2010: 358) describes nogut as polysemous. This is also arguably the case for Sakha, Lavukaleve and Rotokas, as the second person Voluntative-Potential affix, admonitive - $n$ and teapi respectively have multiple senses, which can be judged as related (see Sections 5.3 and 6).

$9 \alpha$ and $\beta$ represent two verb classes (see Robinson 2011: 147-154). 


\section{Tok Pisin}

Lukaut! Nogut yu $\quad$ bagarap!
be.careful NEG.CONSEQUENCE $\quad$ you
'We.ruined
(Aikhenvald 2010: 358)

$\begin{array}{llllll}\text { Nogut } & y u & \text { paitim } & \text { pikinini } & \text { bilong } & \text { mi. } \\ \text { NEG.CONSEQUENCE you } & \text { fight.TR } & \text { child } & \text { of } & \text { me } \\ \text { 'Don't hit my child.' } & & & & \end{array}$

(Baing et al. 2008: 188)

Finally, in Thulung Rai (thul1246, Sino-Tibetan, Kiranti; Eastern Nepal) the lexical verb numu 'to be auspicious/appropriate' has developed (i) into a precautioning suffix via an optative, and (ii) into an impersonal "general prohibitive" marker which denotes 'one should not' (Lahaussois 2018). This contrasts with the negative imperative, which denotes 'don't'. This is arguably a case of heterosemy, which is when historically related meanings/functions "are borne by reflexes of the common source element [but] belong in different morpho-syntactic categories" (Lichtenberk 1991: 476). In Thulung Rai the emphatic particle $s \theta$ also has both apprehensional and prohibitive functions (Lahaussois 2018).

\subsection{Austronesian and Oceanic languages}

Within the Austronesian family, there are several languages where apprehensive and prohibitive morphemes are formally identical/similar. In Tukang Besi (tuka1248, Austronesian; Indonesia), the complementizer bara 'lest' introduces complement clauses of 'fear' or 'persuade' verbs (Donohue 1999: 393; 99-400), and introduces reason (i.e. apprehension-causing) adverbial clauses where it denotes 'lest, so that it not happen' (Donohue 1999: 409). However, bara also denotes 'don't' in independent prohibitive clauses (Donohue 1999: 454). There is another prohibitive form ka'ulu 'don't' which, unlike Papapana ae, differs from negators used in other clauses (Donohue 1999: 453, 48-49).

In Maori (maor1246, Austronesian; New Zealand), the monitory mood particle $k e i$ is used for positive warnings with second or third person subjects in independent clauses (Bauer 1993: 464-65) or introduces complement clauses of fear (Bauer 1993: 40). However, a negative imperative can be expressed by kei, though Bauer (1993: 37) is hesitant about whether kei is the same morpheme as monitory $k e i$, admitting that she was unable to find examples that native speakers found 
ambiguous. Other negative imperatives involve the dedicated negator kaua kauaka aua (Bauer 1993: 35).

Within the Oceanic subgroup, there is similarity between apprehensive and prohibitive constructions in Lolovoli (east2443) and Vatlongos (sout2859), both spoken in Vanuatu, and Äiwoo (ayiw1239), spoken in the Solomon Islands. In the Lolovoli dialect of North-East Ambae, the preverbal apprehensive mood particle bo is only used with second person subjects and expresses an order not to do something but "includes a definite warning component that there will be certain negative consequences if the action described by the verb takes place" (Hyslop 2001: 251). The addressee may be warned against an involuntary action, such as falling, or warned against a negative unintentional result of a voluntary action, such as cutting oneself accidentally while intentionally cutting something else (50). In (50) bo has an apprehensional-epistemic function but it can also have a precautioning function (51), where the main clause prohibitive is marked by the preverbal dehortative particle mese, which "always expresses a command not to perform a volitional action" but carries no implication of negative consequences (Hyslop 2001: 248, 252).

\section{Lolovoli, North-East Ambae}

$$
\begin{aligned}
& \text { Go=bo } \quad \text { tai }=g o . \\
& \text { 2SG.SBJ=APPR } \quad \text { chop=2SG.OBJ } \\
& \text { 'Watch out you don't cut yourself.' } \\
& \text { (Hyslop 2001: 251) }
\end{aligned}
$$

\begin{tabular}{|c|c|c|}
\hline Go=mese & gani=e, & $g o=b o$ \\
\hline 2SG.SBJ=DEHOR & eat=3SG.OBJ & $2 \mathrm{SG} . \mathrm{SBJ}=\mathrm{APPR}$ \\
\hline
\end{tabular}

Example (50) is not a prohibitive: the speaker is not trying to make the addressee "not realize some state of affairs" (Devos and Van Olmen 2013: 22) because the speaker does not think the addressee would volitionally realize the situation. This is also the case for the Hoava and Kubokota examples (14)-(15) in Section 3.1.

For (52), Hyslop (2001: 253) analyses the first clause, with bo, as a warning about the consequences of dealing with black magic, whereas the second clause with mese is an instruction not to use black magic. However, I would argue that both clauses are prohibitives, since the addressee does have control over whether they use black magic, but with bo there is an implication about the negative consequences, whereas with mese there is not. It could be the case that in Lolovoli, the prohibitive use of bo is emerging, perhaps due to the influence of mese in the main clause of precautioning sentences such as (51), or due to a change in 
volition/control (see Section 6.1). Perhaps a similar pathway of development may occur in future for Hoava maki and Kubokota keta (and has occurred in Papapana; see Sections 6.2.2 and 6.2.3).

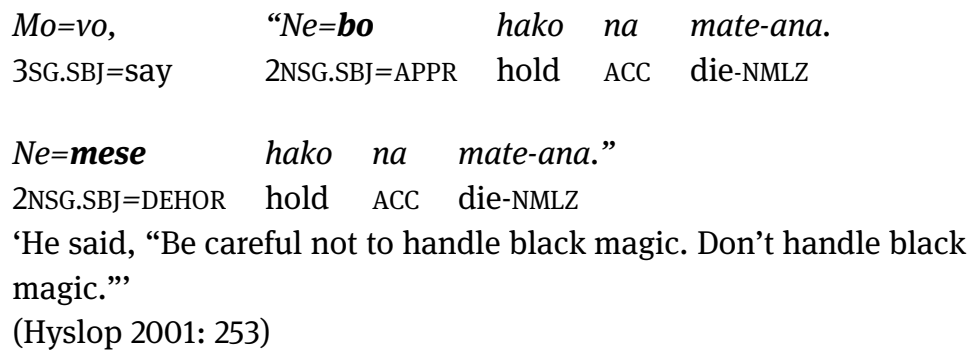

In Vatlongos, the apprehensive mood and prohibitive prefix paradigms overlap. The apprehensive prefix is used for events that are "possible and unwanted", and often "to give a warning to take preventative action" (Ridge 2019: 179) as in (53) where the speaker wants the addressee to avoid the bulls. Apprehensive na-cooccurs with the distant future subject co-referencing prefixes (except in third person singular where it occurs only as na-) (Ridge 2019: 210-211). The resulting apprehensive paradigm overlaps with the prohibitive paradigm (Ridge 2019: 211). The prohibitive prefixes, however, must co-occur with the negative clitic ti to give a prohibitive meaning (Ridge 2019: 209) as in (54). Ridge highlights that the combination of morphemes to mark prohibitive mood is an example of distributed exponence (Ridge 2019: 390), that is, "morphosyntactic and morphosemantic properties are marked non-redundantly at multiple inflectional sites" (Carroll 2016: 286). Therefore, in Vatlongos there is no polysemy because the apprehensive and prohibitive constructions are different, even though they both employ the same prefixes. Nevertheless, the apprehensive and prohibitive prefixes are arguably diachronically related.

\section{Vatlongos}

Wael buluk xi-e mei na-has-uk! wild bull SG-PROX come 3SG.APPR-kill-2SG

'The wild bull might come kill you!'

(Ridge 2019: 179)

(54) On-tangal=ti!

2SG.PROH-make.noise=NEG

'Don't make noise!'

(Ridge 2019: 179) 
In Äiwoo, the apprehensive mood particle de 'lest, in case' appears in independent apprehensive clauses (55) and in apprehension-causing clauses, but it also combines with $=e o \sim=$ io to denote 'don't' in prohibitive clauses (56) (Næss 2017: 29, 37; Næss, pers.comm. 20/06/2019). The other way to express prohibition is with the interjection kaa 'don't' (Næss 2017: 48; pers.comm. 20/06/2019). Næss (pers.comm. 20/06/2019) analyses $=e o \sim=i o$ as the prohibitive marker, and this requires the verb to be marked for apprehensive mood with de. An alternative analysis might suggest that the obligatory combination of $d e$ and $=e o \sim=i o$ is an example of distributed exponence. There is again no polysemy because the apprehensive and prohibitive constructions are not identical, but there is similarity between them because they both employ $d e$.

$$
\begin{aligned}
& \text { Kâ-no=ngä nyenaa de-eobu-mä dä. } \\
& \text { say-1MIN=CV tree APPR-fall-DIR:1 some } \\
& \text { 'I thought a tree might fall down on me [during the cyclone].' } \\
& \text { (Næss, pers.comm. 20/06/2019) }
\end{aligned}
$$

$\begin{array}{ll}\text { De-wâ-tepeu-nâ-mu=io } & i u ! \\ \text { APPR-CAUS-be.stupid-UV-2MIN=PROH } & 1 \mathrm{MIN} \\ \text { 'Don't make fun of me!' } & \end{array}$

(Næss, pers.comm. 20/06/2019)

\subsection{Papapana}

In Papapana apprehensive te co-occurs with irrealis $=i$ in apprehension-causing adverbial clauses (Section 3.2), while prohibitives are formed with monosyllabic or disyllabic verbal reduplication and either preverbal negative ae or preverbal apprehensive te (Section 4.2). Sometimes irrealis $=i$ may also be present in prohibitives and thus the main difference morphologically between the two constructions is the presence of verbal reduplication in prohibitives.

The morpheme te in both constructions is formally identical and occurs in the same syntactic position in the VC. The senses of te in both constructions are also similar: te marks the event as undesirable and to be avoided. In precautioning sentences, the main clause expresses a precaution that can avert the undesirable event or the undesirable consequence of an event expressed in the apprehensioncausing adverbial clause. In prohibitive clauses, the speaker directs the addressee to avoid or cease an action that the speaker deems undesirable. However, it cannot be said that te is polysemous, with two senses that are related, because the apprehensive and prohibitive constructions are not identical and they do not rely 
solely on te for their meaning. Instead, the exponence of these feature values is distributed between te and other morphemes. One might instead consider whether te has one unified meaning, perhaps 'undesirable', and the difference in interpretation between apprehensive and prohibitive is contributed by the morphology in which the constructions differ. In this case, the apprehensive construction would be compositional, with irrealis $=i$ contributing the possibility component (as it does elsewhere) and te contributing the undesirability component. However, the prohibitive construction is not as convincingly compositional because verbal reduplication does not have a unified meaning like irrealis $=i$, and unlike irrealis $=i$, verbal reduplication always has to combine with another morpheme, whether in prohibitive, reciprocal or imperfective aspect constructions. Therefore, I argue in Section 6 that diachronically, the apprehensive and prohibitive meanings are related and that one construction with te developed from the other.

\section{Development of apprehensive/prohibitive similarity}

This section considers how similarity between apprehensive and prohibitive morphemes might have developed and in which direction. Section 6.1 starts with Pakendorf and Schalley (2007) who propose that meanings of prohibition develop from meanings of possibility and apprehension. Section 6.2 investigates whether the Papapana data support this proposed pathway, and the motivations and mechanisms for this semantic change.

\subsection{Possibility to prohibition via apprehensives and admonitives/preventives}

Pakendorf and Schalley (2007: 525) propose that in a small number of the world's languages, the prohibitive has developed from "an affirmative form with an original meaning of possibility" and/or desire, via intermediate stages of apprehension and warning:

$$
\text { possibility } \rightarrow \text { apprehension } \rightarrow \text { warning } \rightarrow \text { prohibition }
$$

Pakendorf and Schalley (2007: 525) assume that the affirmative meaning is primary because in the languages discussed, (i) the affirmative is not restricted to specific person reference, but the prohibitive is restricted to second person, and (ii) most 
forms "can either be negated regularly (Sakha, Belhariya, and Navajo) or cannot co-occur at all with regular negative markers (Chepang and Lavukaleve)".

Pakendorf and Schalley (2007: 533-35) also discuss languages for which development from possibility to prohibition is incomplete. In Kannada (nucl1305, Dravidian; India) and three Australian languages, Murrinh-Patha (murr1258, Daly), Wambaya (wamb1258, West Barkly), and Nyangumarta (nyan1301, PamaNyungan), only the first half of the pathway (possibility $\rightarrow$ apprehension $\rightarrow$ warning) is represented, while Maori kei highlights the second half (apprehension/ warning $\rightarrow$ prohibition).

Pakendorf and Schalley (2007: 528) propose that development from possibility to prohibition involves a conventionalization of conversational implicatures, a process argued to be involved in grammaticalisation (see, e.g. Bybee et al. 1994: 196-197; Heine et al. 1991: 71-72; Traugott 1989). This process involves a particular form having certain inferences in certain contexts, which can be exploited/invited by the speaker. These inferences can become semanticised, that is, part of the encoded meaning, via a stage of conventionalization of the inference, during which both the original and new meaning are possible. For the development of prohibition from possibility, Pakendorf and Schalley (2007: 528) thus propose:

The fact of voicing one's apprehension, i.e., fear of bad consequences, to an addressee often contains a warning to that addressee to do whatever needs to be done to avoid the consequences of his/her action... In turn, a warning can be viewed as an incipient prohibition, since the most certain way of ensuring that the addressee avoids an action that might be followed by bad consequences is to prohibit it altogether. (Pakendorf and Schalley 2007: 528)

The intermediate meaning of apprehension encodes undesirability and possible negative consequences, and "this negative meaning carries over to the prohibitive meaning even without formal negative marking” (Pakendorf and Schalley 2007: 528-529). What Pakendorf and Schalley do not explain is how or why a meaning of neutral possibility extends to undesirable possibility. Pakendorf and Schalley 2007: 530) suggest their proposed pathway runs counter to the "proposed unidirectionality of development of epistemic modality out of deontic modality" (see, e.g., Bybee et al. 1994: 195; Heine et al. 1991: 175-178; Traugott 1989).

Pakendorf and Schalley (2007) do not mention, however, that Bybee et al. (1994: 211) also acknowledge an "unexpected set of examples" from Alyawarra (alya1239, Pama-Nyungan; Australia) and Slave (slav1253, Athabaskan; Canada), which demonstrate a shift in the opposite direction, from epistemic or root possibility to admonitive mood (a speaker-oriented modality) when the sense of possibility contains "the notion that the possible situation is unpleasant, dangerous, or deleterious". Like Pakendorf and Schalley (2007), Bybee et al. (1994: 211-212) also discuss Chepang (chep1245, Sino-Tibetan; Nepal) where the possibility marker 
does not carry the deleterious implication but can be used to issue a warning in the second person. They cite Caughley (1982: 102) who explains that originally the addressee was warned about something in which they were not intentionally involved, but then this warning was extended to cases where the addressee could have control, and was thus interpreted as a prohibition.

This difference in volition and control is key to distinguishing semantically between 'prohibitive' and 'preventive' negative imperatives in Slavic languages (formally, these are differentiated by aspect and the verb's semantic class). In prohibitive constructions, the speaker demands that the addressee stops or refrains from an activity which brings about an unwanted situation and "believes that the addressee is willing and able to comply" (Kuehnast 2008: 178). In preventive constructions, the speaker warns the addressee of "undesirable consequences which are predictable from his/her current activities" (Kuehnast 2008: 189) and the speaker believes that the addressee is unaware of the undesirable consequence of his/her activities and cannot control and/or does not intend it (Kuehnast 2008: 178, 192). The imperative force is directed to an activity or state which the addressee can actually control, but their current activities are not mentioned (Kuehnast 2008: 192). It could be argued that Kubokota and Hoava examples (14)-(15) (Section 3.1) and Lolovoli example (50) (Section 5.2) are preventives since the addressee is warned against an involuntary action which will have a negative effect on them, or a negative unintentional result of a voluntary action.

Dobrushina (2006: 62) ${ }^{10}$ also notes that in many dialects of the Yakut language (Sakha), there is a parameter of indirect mood which combines probabilistic, apprehensive, preventive and prohibitive uses and she also suggests that the prohibitive developed from the apprehensive. However, Dobrushina proposes that the semantic link on the pathway from apprehensives to prohibitives is a preventive (58). It is not clear at what stage a probabilistic value arises but it is assumed that it develops from the apprehensive (58). Dobrushina (2006: 63) also suggests this pathway for Lavukaleve though with probability preceding apprehensive.

$$
\begin{aligned}
\text { apprehensive } & \rightarrow \text { preventive } \rightarrow \text { prohibitive } \\
& \rightarrow \text { probability }
\end{aligned}
$$

Similar to Pakendorf and Schalley (2007: 528), Dobrushina (2006: 62) suggests that this development arises because a statement about the occurrence of a possible, undesirable, future action is reinterpreted as an instruction to avoid this situation

10 I thank an anonymous reviewer of my 13th Association for Linguistic Typology conference abstract for providing a translation of excerpts from this paper. 
by some other action. If Lolovoli example (50) is seen as preventive, then this supports Dobrushina's pathway as a prohibitive use of bo appears to be emerging when the addressee does have control over the action (52).

\subsection{Apprehensive to/from prohibitive in Papapana}

We now turn to the relationship between te in apprehensive and prohibitive clauses in Papapana: did a prohibitive morpheme gain an apprehensive meaning or did an apprehensive morpheme gain a prohibitive meaning, and why and how did this happen?

\subsubsection{Prohibitive to apprehensive}

One hypothesis is that te was originally a prohibitive morpheme (which combined with verbal reduplication and optionally irrealis $=i$ ) and it developed into an apprehensive morpheme (which combined only and obligatorily with irrealis $=i$ ).

Since prohibitives in Papapana can also be formed with negative $a e$, verbal reduplication and optionally irrealis $=i$, then this hypothesis assumes either (a) that both te and ae were originally used in prohibitive constructions or (b) that $a e$ at some stage began to negate imperatives as well as declaratives, thus creating a contrast with the existing prohibitive construction involving te. Scenario (a) seems unlikely as it is unusual for Oceanic languages to have two prohibitive morphemes. Scenario (b) is plausible as Oceanic languages often have distinct negative markers for declaratives and imperatives (Section 4.1). However, we then have to explain why ae began to negate imperatives as well as declaratives. It is certainly possible that negative ae could have extended its scope, or perhaps as Papapana has become more endangered, speakers are forgetting and/or replacing te with the declarative negator. However, te is apparently used when prohibiting a commenced action/state whereas ae prohibits something not yet commenced (Section 4.3), so if scenario (b) is correct, there would not previously have been a way to express general prohibition of actions (commenced or not) and this seems unlikely. Alternatively, te lost this function and specialized as a cessative prohibitive but then we have to explain why this happened and why it specialized in this way. Even if we follow my hypothesis in Section 4.3 - that ae is used for general prohibition of actions (commenced or not), and te is restricted to commenced actions and/or has overtones of warning/urgency - then we would still have to explain why te became more specialized.

In addition, this hypothesis assumes that Papapana did not have an apprehensive mood category, or that it perhaps lost it at an earlier stage before 
developing a new one. While both of these scenarios are possible, it is arguably more likely that Papapana did have an apprehensive mood category to begin with, since Oceanic languages often have apprehensives (Section 3.1).

\subsubsection{Apprehensive to prohibitive}

The other hypothesis is that te was originally an apprehensive morpheme (which combined only and obligatorily with irrealis $=i$ ) and that it developed into a prohibitive morpheme (which combined with verbal reduplication and optionally irrealis $=i$ ). The addition of verbal reduplication is arguably by analogy with the (assumed to be) already existing prohibitive construction involving negative ae.

It is likely that te was originally apprehensive as Oceanic languages often have apprehensive morphemes (Section 3.1). It is also likely that there was one prohibitive morpheme as it is unusual for Oceanic languages to have two prohibitive morphemes (Section 4.3). Although less likely, it is possible that ae is the original negator in prohibitives because some Oceanic languages do use the same negator in both declaratives and imperatives (Section 4.1). Certainly ae is a widespread negator in Papapana (Section 2.3) whereas te is not. That ae is the original negator in prohibitives is more strongly supported by the fact that use of $a e$ in a prohibitive clause is two times more frequent than the use of te in my text corpus.

This hypothesis presupposes that there were originally two constructions which each had their own functions, which is economical, and that an additional prohibitive construction with te was created. However, we then need to explain why an additional prohibitive construction was created. Although it is unusual in Oceanic languages to have two prohibitive constructions, cross-linguistically this is not necessarily the case: for example, in a sample of 100 Bantu languages, Devos and Van Olmen (2013: 44) find there is "more variation in the forms used for the directive with negative directionality" than those with positive directionality. One of the factors they propose to explain this variation is that negative directives have "a number of functional subtypes, such as the cessative and the warning... Speakers may feel the need to make such distinctions explicit... and the forms that they use may develop into new general prohibitival strategies" (Devos and Van Olmen 2013: 45). This could be why a prohibitive with te developed in Papapana. Recalling the distinctions between ae and te made in Section 4.3, we could argue that speakers wanted to make explicit the cessative or warning function of the negative directive by using te. This is similar to Lolovoli for which I argued that a prohibitive use of apprehensive bo is emerging that contrasts with mese prohibitives, which lack a warning/implication of undesirable consequences (Section 5.2). Another motivation could be politeness: prohibiting someone from doing something they have already commenced constitutes an unfavourable evaluation 
of the addressee's current behaviour and this is more face-threatening than evaluating their expected behaviour, or than a general, impersonal prohibition. Speakers therefore develop a new (perhaps initially more indirect) strategy, a prohibitive with te, to perform this more face-threatening speech act.

Finally, this hypothesis is also likely from a syntactic point of view: apprehension-causing clauses with te can have second or third person subjects, while prohibitive clauses with te only have second person subjects. Therefore, in apprehensive constructions, te is less restricted to specific person reference, but is then restricted to second person once it has been extended to prohibitive constructions.

\subsubsection{The pathway of change and insubordination}

If we accept that te was originally an apprehensive morpheme that developed into a prohibitive morpheme, we need to explain not only why this happened, but how. The answer is arguably that the apprehension-causing subordinate clause has developed into a prohibitive main clause via insubordination. Insubordination is "the conventionalized main clause use of what... appear to be formally subordinate clauses", with the subordinate clauses either being finite or non-finite (Evans 2007: 367). Sometimes such clauses are treated "as underlying subordinate clauses from which some sort of main clause has been ellipsed” (Evans 2007: 367). Indeed, this is the approach taken by Austin (1981) for Diyari and an argument I proposed for Papapana for those few examples from April 2018 (Section 3.3.1). However, Evans takes the insubordination approach when analysing Diyari, which has a special subordinate verb form, the 'lest' or apprehensive form. For Evans, (59) is an example of a 'typical' subordinate use, while (60) is an example of an 'insubordinated' independent use, rather than being subordinate to an implicit main clause (Austin 1981: 229).

\section{Diyari}

Makita padaka-O-mayi, wanku yundu wala nayi-yati. gun-ABS take-IMP-EMPH snake-ABS 2SG.A soon see-lest

'Carry a gun in case you see a snake.'

(Austin 1981: 225)

\begin{tabular}{|c|c|c|}
\hline $\begin{array}{l}\text { Kulu-ka } \\
\text { 3SG.NF.A-TOKEN }\end{array}$ & $\begin{array}{l}\text { kintaya-li } \\
\text { dog-ERG }\end{array}$ & $\begin{array}{l}\text { yinana } \\
\text { 2SG.OBJ }\end{array}$ \\
\hline $\begin{array}{l}\text { This dog migh } \\
\text { (Austin 1981: } 2\end{array}$ & $\begin{array}{l}\text { bite you.' } \\
\text { 9) }\end{array}$ & \\
\hline
\end{tabular}


Insubordinated clauses can have a range of functions, including commands and warnings (Evans 2007: 368). Evans (2007: 368, 370-372) proposes that diachronically, these functions arise through a four-step process: (i) subordinate construction; (ii) ellipsis of the main clause (which is reconstructed by the addressee); (iii) conventionalized restriction of interpretation of the ellipsed material; and (iv) conventionalized main clause use, whereby it may not be possible to restore any ellipsed material and the construction now has its own specific meaning. Such a pathway involves "an opening up, then a closing, of the role of pragmatics" and therefore insubordination goes against much of the existing research on morphosyntactic change which asserts a unidirectional pathway from pragmatics to syntax to morphology and focuses on subordinate constructions developing from main clause material (Evans 2007: 374-375).

In Papapana, apprehension-causing adverbial clauses are finite because they have subject-indexing proclitics, but they are analysed as subordinate because there is no strong evidence that the combination of apprehensive te and irrealis $=i$ can function in an independent apprehensive clause (Section 3.3). In Section 3.3.1, I presented a few examples where a clause containing the apprehensive te and irrealis $=i$ (with a non-reduplicated verb) does occur independently. However, these examples come from only one speaker in elicitation sessions in April 2018 and I argued that the speaker had an implicit precaution clause in mind, or was biased by the discussion or Tok Pisin nogut. There are certainly no examples in the text data of an independent apprehensive clause. Therefore, I do not think the examples in Section 3.3.1 are 'insubordinated' independent clauses. However, these examples could represent the intermediate steps (ii) and/or (iii) of the insubordination process. Perhaps the utterances in April 2018 occurred because the change is recent or incomplete.

The pathway of development from apprehensive te to prohibitive te via insubordination would therefore tentatively be as follows:

Stage 1: There is one type of prohibitive clause (with negative ae). In precautioning sentences, there is no restriction on the clause type nor subject of the main precaution clause. The precaution clause and the apprehension-causing subordinate clause may or may not be joined by a subordinator.

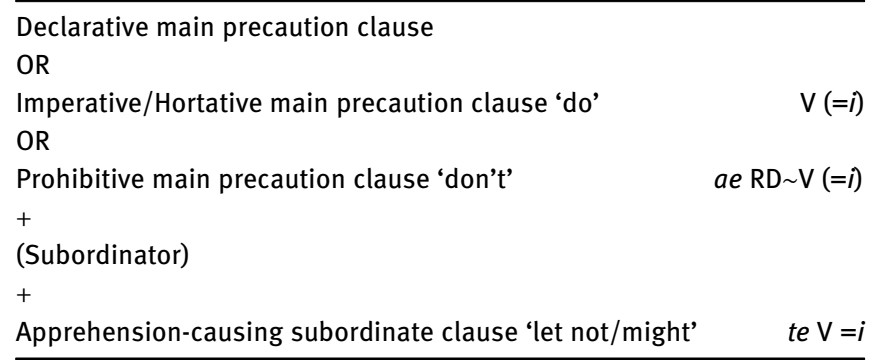


Stage 2: The main precaution clause is ellipsed and reconstructed by the addressee. The optional/occasional use of a subordinator in Stage 1 may have aided this ellipsis.

(Ellipsed main precaution clause, reconstructed by addressee)

Apprehension-causing subordinate clause 'let not/might'

te $\mathrm{V}=i$

\section{Stage 3:}

The statement about a possible, undesirable situation may implicate a warning about a situation over which the addressee has no control or volition, such as the army lying in (19). However, the warning becomes restricted to situations that the addressee can prevent by some other action. This is supported by the fact that (19) is the only example in the text data where the apprehension-causing clause unequivocally has an 'in case' interpretation. Since the addressee is warned about something they can prevent, the interpretation of the ellipsed precaution clause becomes restricted to imperatives/hortatives/prohibitives and to first/second person. This is supported by there being only one example in the corpus of a declarative main clause with a third person subject (21). The apprehension-causing clause is thus associated with and consequently implicates a command, and puts the face-threatening act 'off record'. Similar to my hypothesis for Lolovoli bo (Section 5.2), the implicated command in Papapana becomes more associated with negative polarity and gains prohibitive overtones. In Papapana this is perhaps due to precautioning sentences usually having an 'avertive' function, thus te denotes 'X so that not Y' or 'if not X, then Y'. Stage 3 thus corresponds to Pakendorf and Schalley's (2007) intermediate warning stage, and Dobrushina's (2006) intermediate preventive stage, with the warning/preventive then viewed as an incipient prohibition (Section 6.1).

(Ellipsed imperative/hortative/prohibitive main precaution clause, reconstructed by addressee)

Apprehension-causing subordinate clause 'let not/might/don't'

te $\quad \mathrm{V}=i$

Stage 4: The addressee gains control/volition over the possible, undesirable situation expressed by the clause (rather than control/volition over the ellipsed precaution). The inference is conventionalized and the prohibitive implicature becomes semanticised, as Pakendorf and Schalley's (2007) also suggest (Section 6.1). It is no longer possible to restore any ellipsed material.

Conventionalized main clause use 'don't' te $\quad \mathrm{V}=i$


Stage 5: This stage moves beyond Evans' (2007) process. At this stage, the verb is reduplicated and irrealis $=i$ becomes optional, by analogy with the existing prohibitive construction.

One final point is that this pathway of development from apprehensive te to prohibitive te could have been influenced by contact with Rotokas and/or Tok Pisin where teapi and nogut respectively have both apprehensive and prohibitive meanings (Section 5.1). This could be a case of calquing, whereby the meaning range of te in Papapana has been extended because speakers have copied the patterns of meaning of teapi and nogut, and/or it could even be that te derives from teapi. This hypothesis, however, requires further investigation of the syntactic statuses and historical development of these morphemes.

\section{Conclusion}

This paper contributes to the growing body of research on the under-studied precautioning sentence and to the debate about the syntactic status of apprehensives, by analysing the morphosyntax of precautioning sentences in the lesser-known language Papapana (Section 3.2) and arguing that Papapana apprehension-causing clauses are subordinate (Section 3.3). This paper builds on Pakendorf and Schalley's (2007) research by not only showing that there is formal similarity between apprehensives and prohibitives in Papapana, but in other languages too, including Papuan, Austronesian and a Sino-Tibetan language (Sections 5.1 and 5.2). Like Papapana (see Sections 4.2 and 4.3), in many of these languages, there is another prohibitive construction, unrelated to apprehensives. While in some of the languages, the apprehensive and prohibitive morphemes are arguably polysemous, the same cannot be said for Papapana, and instead I propose that $t e$ in apprehension-causing clauses and te in prohibitives are simply diachronically related (Section 5.3). I argued that the Papapana data supports the second half of Pakendorf and Schalley's (2007) grammaticalization path from apprehension to prohibition (Section 6.2.2) and that the additional prohibitive clause with te was created via a process insubordination and analogical extension 
with warning and/or prevention being a critical semantic link (Section 6.2.3). It could be suggested that this pathway is not as rare as Pakendorf and Schalley (2007) thought. However, I do not agree with their claim that their data contradict "the general tendency observed by others that the development of modal meanings proceeds from deontic modality to epistemic modality" (Pakendorf and Schalley 2007: 537), because prohibitives are arguably not deontic. Following Timberlake (2007) and Nuyts, Byloo, and Diepeveen (2010), I consider prohibitives to be directive. For Timberlake, directive is a type of modality where the speaker, as authority, asks the addressee to act as a proxy authority and change the world from its inertial path whereas with deontic modality "a general authority asks a proxy authority to act” (Timberlake 2007: 329). Nuyts, Byloo, and Diepeveen (2010: 16) argue that deontic modality should be defined in terms of (degrees of) moral acceptability or necessity rather than permission and obligation. This is distinct from directives, which they consider in speech act terms, as attempts "by the speaker to get the hearer to do something" (Searle 1976: 11). Indeed elsewhere, imperative and prohibitive are also considered as pertaining to illocutionary type rather than modality (see van der Auwera and Plungian 1998: 83). Furthermore, even if I did agree with Pakendorf and Schalley's unjustified assumption that prohibitives/negative imperatives are "clearly deontic in their meanings" (Pakendorf and Schalley 2007: 537), the Papapana data would not contradict the pathway of deontic to epistemic modality because (i) there is no evidence that Papapana supports the first half of Pakendorf and Schalley's (2007) grammaticalization path which starts with possibility, and (ii) apprehensives are a mixed modality which are both epistemic and attitudinal (Lichtenberk 1995: 291). In fact it is this attitudinal component which could aid the development from apprehensive to prohibitive, since according to Timberlake (2007: 330), directive and attitudinal modality overlap.

An area for further research is the diachronic source of apprehensive te. Beyond Papapana, it would also be interesting to investigate the prohibitive use of teapi in Rotokas to see if there is evidence of calquing or lexical borrowing, and in which direction. It would also be interesting to observe whether the modal negative maki in Hoava and the adverb keta 'lest' in Kubokota develop into prohibitive morphemes. While it is clear that formal similarity between apprehensives and prohibitives is quite widespread in the Pacific region, it would be worth exploring whether there are more languages beyond the Pacific region where a relationship between apprehensives and prohibitives exists. This would help us to more firmly establish the pathway from apprehension to prohibition. 


\section{Abbreviations}

1

2

3

A

ABL

ABS

ACC

ADV

ALL

APPL

APPR

ATTRIB

CAUS

CLI

CLII

COM

COMPL

COND

CONT

CV

DEHOR

DEM1

DEM2

DETR

DIR

EMPH

ERG

EXCL

HORT

IMP

INCL

INTS

IP

IPFV

IRR

LOC

MIN

N

NEG

NEG:WARN

NEG.CONSEQUENCE

$\mathrm{NF}$

NMLZ

NSG
First person

Second person

Third person

Transitive subject

Ablative

Absolutive

Accusative

Adverbial

Allative

Applicative

Apprehensive

Attributive

Causative

Noun class I

Noun class II

Comitative

Completive

Conditional

Continuous

Circumstantial voice

Dehortative

Demonstrative 1

Demonstrative 2

Detransitive

Directional

Emphatic

Ergative

Exclusive

Hortative

Imperative

Inclusive

Intensifier

Immediate past

Imperfective

Irrealis

Locative

Minimal number

Neuter

Negative

Negative warning

Negative consequence

Non-feminine gender

Nominaliser

Non-singular 


$\begin{array}{ll}\text { NSPEC } & \text { Nonspecific } \\ \text { OBJ } & \text { Object } \\ \text { OBL } & \text { Oblique } \\ \text { OPT } & \text { Optative } \\ \text { PART } & \text { Partitive } \\ \text { PASS } & \text { Passive } \\ \text { PERS } & \text { Personal noun class } \\ \text { PL } & \text { Plural } \\ \text { PPRO } & \text { Personal pronoun } \\ \text { PRO } & \text { Pronoun } \\ \text { PROH } & \text { Prohibitive } \\ \text { PROX } & \text { Proximal } \\ \text { PSSR } & \text { Possessor } \\ \text { PST } & \text { Past } \\ \text { R/R } & \text { Reciprocal/reflexive } \\ \text { RD } & \text { Reduplicant } \\ \text { RECP } & \text { Reciprocal } \\ \text { REP } & \text { Repetitive } \\ \text { REST } & \text { Restrictive particle } \\ \text { SBJ } & \text { Subject } \\ \text { SBJV } & \text { Subjunctive } \\ \text { SEQ } & \text { Sequential } \\ \text { SG } & \text { Singular } \\ \text { SPEC } & \text { Specific } \\ \text { SUBR } & \text { Subordinator } \\ \text { TOKEN } & \text { Token } \\ \text { TR } & \text { Transitive } \\ \text { UV } & \text { Undergoer voice } \\ & \end{array}$

Acknowledgments: I would like to thank the anonymous reviewers of my conference paper abstracts and the delegates at those conferences, for their comments in the early stages of this research (the 8th Syntax of the World's Languages, 11th International Austronesian and Papuan Languages and Linguistics and 13th Association for Linguistic Typology conferences). Thank you to Daniël Van Olmen for commenting on an earlier draft of this paper and to Johan van der Auwera and three anonymous reviewers for their very helpful, detailed feedback. I also wish to thank everyone in Bougainville who assisted me in my fieldwork, especially the Papapana community. Most of the data upon which this research is based come from a project funded by the Endangered Language Documentation Programme and I gratefully acknowledge their Major Documentation Project grant MDP0206. I also thank the Social Sciences Research Development Fund and the Applied Linguistics department at the University of Warwick for funding and supporting my 2018 fieldwork. 


\section{References}

Aikhenvald, Alexandra Y. 2003. A grammar of Tariana, from Northwest Amazonia. Cambridge: Cambridge University Press.

Aikhenvald, Alexandra Y. 2010. Imperatives and commands. Oxford: Oxford University Press. Angelo, Denise \& Eva Schultze-Berndt. 2016. Beware bambai - Lest it be apprehensive. In Felicity Meakins \& Carmel O'Shannessy (eds.), Loss \& renewal: Australian languages since colonisation, 255-96. Berlin: Mouton de Gruyter.

Austin, Peter. 1981. A grammar of Diyari, South Australia. Cambridge: Cambridge University Press. Baing, Susan, Brian Deutrom, Russell Jackson \& C. A. Volker. 2008. Papua New Guinea Tok Pisin English dictionary. Melbourne: Oxford University Press.

Bauer, Winifred. 1993. Maori. London: Routledge.

Bybee, Joan, Revere Perkins \& William Pagliuca. 1994. The evolution of grammar: Tense, aspect, and modality in the languages of the world. Chicago: University of Chicago Press.

Carroll, Matthew. 2016. The Ngkolmpu language with special reference to distributed exponence. Australian National University PhD thesis.

Caughley, Ross C. 1982. The syntax and morphology of the verb in Chepang. Canberra: Pacific Linguistics.

Chambers, Mary. 2009. Which way is up? Motion verbs and paths of motion on Kubokota, an Austronesian language of the Solomon Islands. School of Oriental \& African Studies, University of London PhD thesis.

Corston, Simon. 1996. Ergativity in Roviana, Solomon Islands. Canberra: Pacific Linguistics.

Corston-Oliver, Simon. 2002. Roviana. In John Lynch, Malcolm Ross \& Terry Crowley (eds.), The Oceanic languages, 467-497. Richmond: Curzon Press.

Davis, Karen. 2003. A grammar of the Hoava language, Western Solomons. Canberra: Pacific Linguistics.

Dench, Alan. 1988. Complex sentences in Martuthunira. In Peter Austin (ed.), Complex sentence constructions in Australian languages, 97-139. Amsterdam/Philadelphia: John Benjamins Publishing.

Devos, Maud \& Daniël Van Olmen. 2013. Describing and explaining the variation of Bantu imperatives and prohibitives. Studies in Language 37(1). 1-57.

Dixon, R. M. W. 1977. A grammar of Yidin. Cambridge: Cambridge University Press.

Dixon, R. M. W. 1988. A grammar of Boumaa Fijian. Chicago: University of Chicago Press.

Dixon, R. M. W. 2009. The semantics of clause linking in a typological perspective. In R. M. W. Dixon \& Alexandra Y. Aikhenvald (eds.), The semantics of clause linking: A crosslinguistic typology, 1st edn., 1-55. Oxford: Oxford University Press.

Dobrushina, Nina. 2006. Grammaticheskie formy i konstrukcii so znacheniem opasenija i predosterezhenija [Grammatical forms expressing warning and apprehension]. Voprosy jazykoznanija 2. 28-67.

Donohue, Mark. 1999. A grammar of Tukang Besi. Berlin: Mouton de Gruyter.

Early, Robert. 2002. Niuafo'ou. In John Lynch, Malcolm Ross \& Terry Crowley (eds.), The Oceanic languages, 848-864. Richmond: Curzon Press.

Evans, Nicholas. 1995. A grammar of Kayardild: With historical-comparative notes on Tangkic. Berlin: Mouton de Gruyter.

Evans, Nicholas. 2007. Insubordination and its uses. In Irina Nikolaeva (ed.), Finiteness: Theoretical and empirical foundations, 366-431. Oxford: Oxford University Press. 
Fagan, Joel L. 1986. A grammatical analysis of Mono-Alu (Bougainville Straits, Solomon Islands). Canberra: Pacific Linguistics.

François, Alexandre. 2003. La sémantique du prédicat en mwotlap (Vanuatu). Société de Linguistique de Paris. Leuven-Paris: Peeters.

Frostad, Benedicte H. 2012. A grammar of Ughele: An Oceanic language of Solomon Islands. Utrecht: Landelijke Onderzoekschool Taalwetenschap.

Geraghty, Paul. 2002. Nadrogā. In John Lynch, Malcolm Ross \& Terry Crowley (eds.), The Oceanic languages, 833-847. Richmond: Curzon Press.

Glennon, John J. 2014. Syntactic ergativity in Nehan. Dallas: The Graduate Institute of Applied Linguistics MA thesis.

Heine, Bernd, Ulrike Claudi \& Friederike Hünnemeyer. 1991. Grammaticalization: A conceptual framework. Chicago: University of Chicago Press.

Hill, Deborah. 2002. Longgu. In John Lynch, Malcolm Ross \& Terry Crowley (eds.), The Oceanic languages, 538-561. Richmond: Curzon Press.

Hyslop, Catriona. 2001. The Lolovoli dialect of the North-East Ambae language, Vanuatu. Canberra: Pacific Linguistics.

Kajitani, Motomi. 2005. Semantic properties of reduplication among the world's languages. LSO Working Papers in Linguistics. Proceedings of WIGL 5. 93-106.

Kroeker, Menno. 2001. A descriptive grammar of Nambiquara. International Journal of American Linguistics 67. 1-87.

Kuehnast, Milena. 2008. Aspectual coercion in Bulgarian negative imperatives. In Werner Abraham \& Elisabeth Leiss (eds.), Modality-aspect interfaces: Implications and typological solutions, (Typological studies in language 79), 175-196. Amsterdam/ Philadelphia: John Benjamins Publishing.

Lahaussois, Aimée. 2018. Inauspicious events in Thulung Rai. Paper presented at the 8th Syntax of the World's Languages, Institut national des langues et civilisations orientales, 3-5 September 2018.

Lichtenberk, Frantisek. 1991. Semantic change and heterosemy in grammaticalization. Language 67(3). 475-509.

Lichtenberk, Frantisek. 1995. Apprehensional epistemics. In Joan Bybee \& Suzanne Fleischman (eds.), Modality in grammar and discourse, (Typological Studies in Language 32), 293-327. Amsterdam \& Philadelphia: John Benjamins Publishing Company.

Lynch, John. 2002a. Cèmuhî. In John Lynch, Malcolm Ross \& Terry Crowley (eds.), The Oceanic languages, 753-764. Richmond: Curzon Press.

Lynch, John. 2002b. laai. In John Lynch, Malcolm Ross \& Terry Crowley (eds.), The Oceanic languages, 776-791. Richmond: Curzon Press.

Lynch, John. 2002c. Puluwatese. In John Lynch, Malcolm Ross \& Terry Crowley (eds.), The Oceanic languages, 804-814. Richmond: Curzon Press.

Lynch, John. 2002d. Ulithian. In John Lynch, Malcolm Ross \& Terry Crowley (eds.), The Oceanic languages, 792-803. Richmond: Curzon Press.

Lynch, John \& Malcolm Ross. 2002. Banoni. In John Lynch, Malcolm Ross \& Terry Crowley (eds.), The Oceanic languages, 440-445. Richmond: Curzon Press.

Lynch, John, Malcolm Ross \& Terry Crowley. 2002. The Oceanic languages. Richmond: Curzon Press.

Mosel, Ulrike. 1999. Towards a typology of negation in Oceanic languages. In Even Hovdhaugen \& Ulrike Mosel (eds.), Negation in Oceanic languages: Typological studies, 1-19. München: Lincom Europa. 
Mosel, Ulrike \& Yvonne Thiesen. 2007. The Teop sketch grammar. http://www.linguistik.uni-kiel. de/Teop_Sketch_Grammar_May07.pdf (accessed 17 May 2011).

Næss, Åshild. 2017. A short dictionary of Äiwoo. Canberra: Asia-Pacific Linguistics.

Nuyts, Jan, Pieter Byloo \& Janneke Diepeveen. 2010. On deontic modality, directivity, and mood: The case of Dutch mogen and moeten. Journal of Pragmatics 42. 16-34.

Pakendorf, Brigitte \& Ewa Schalley. 2007. From possibility to prohibition: A rare grammaticalization pathway. Linguistic Typology 11. 515-540.

Palmer, Bill. 2002. Kokota. In John Lynch, Malcolm Ross \& Terry Crowley (eds.), The Oceanic languages, 498-524. Richmond: Curzon Press.

Palmer, Bill. 2009a. Kokota grammar. Honolulu: University of Hawai'i Press.

Palmer, Bill. 2009b. Non-morphological reduplication in Torau. Paper presented at the Morphology of the World's Languages, University of Leipzig, 11-13 June 2009.

Palmer, Bill. 2011. Subject-indexing and possessive morphology in Northwest Solomonic. Linguistics 49(4). 685-747.

Palmer, Frank R. 2001. Mood and modality, 2nd edn. Cambridge: Cambridge University Press.

Payne, Thomas E. 1997. Describing morphosyntax: A guide for field linguists. Cambridge: Cambridge University Press.

Ridge, Eleanor. 2019. Variation in Vatlongos Verbal Morphosyntax: Speaker communities in Southeast Ambrym and Mele Maat. London: School of Oriental and African Studies, University of London PhD dissertation. https://eprints.soas.ac.uk/32205/.

Robinson, Stuart. 2011. Split intransitivity in Rotokas, a Papuan language of Bougainville. Nijmegen: Max Planck Institute for Psycholinguistics.

Ross, Malcolm. 2002a. Sisiqa. In John Lynch, Malcolm Ross \& Terry Crowley (eds.), The Oceanic languages, 456-466. Richmond: Curzon Press.

Ross, Malcolm. 2002b. Taiof. In John Lynch, Malcolm Ross \& Terry Crowley (eds.), The Oceanic languages, 426-439. Richmond: Curzon Press.

Saeed, John I. 2016. Semantics, 4th edn. Chichester: Wiley Blackwell.

Schmidtke-Bode, Karsten. 2009. A typology of purpose clauses. Amsterdam/Philadelphia: John Benjamins Publishing.

Schütz, Albert J. 1985. The Fijian language. Honolulu: University of Hawaii Press.

Searle, John. 1976. A classification of illocutionary acts. Language in Society 5. 1-23.

Smith, Ellen. 2015. Documenting Papapana, a highly endangered Northwest Solomonic language of the Autonomous Region of Bougainville, Papua New Guinea. Endangered Languages Archive. http://elar.soas.ac.uk/deposit/0313.

Smith, Ellen. 2016a. Contact-induced change in a highly endangered language of Northern Bougainville. Australian Journal of Linguistics 36(3). 369-405.

Smith, Ellen. 2016b. Measuring and understanding ethnolinguistic vitality in Papapana. In Luna Filipović \& Martin Pütz (eds.), Endangered languages and languages in danger: Issues of documentation, policy and language rights, (IMPACT: Studies in Language \& Society 42), 249-279. Amsterdam \& Philadelphia: John Benjamins Publishing Company.

Smith, Ellen. 2016c. Papapana re redu reduplicates: Multiple reduplication in an endangered Northwest Solomonic language. Oceanic Linguistics 55(2). 522-560.

Smith-Dennis, Ellen. 2020. A grammar of Papapana: An Oceanic language of Bougainville, Papua New Guinea. Boston/Berlin: De Gruyter Mouton.

Terrill, Angela. 2003. A grammar of Lavukaleve. Berlin: Mouton de Gruyter. 
Timberlake, Alan. 2007. Aspect, tense, mood. In Timothy Shopen (ed.), Language typology and syntactic description, Volume 2: Complex constructions, 2nd edn., 280-333. Cambridge: Cambridge University Press.

Todd, Evelyn M. 1978. A sketch of Nissan (Nehan) grammar. In Stephen A. Wurm \& Lois Carrington (eds.), Second international conference on Austronesian linguistics: Proceedings. Fascicle 2: Eastern Austronesian, 1181-1239. Canberra: Pacific Linguistics.

Traugott, Elizabeth C. 1989. On the rise of epistemic meanings in English: An example of subjectification in semantic change. Language 65(1). 31-55.

van der Auwera, Johan \& Ludo Lejeune. 2013. The prohibitive. In Matthew S. Dryer \& Martin Haspelmath (eds.), The world atlas of language structures online. Leipzig: Max Planck Institute for Evolutionary Anthropology.

van der Auwera, Johan \& Vladimir A. Plungian. 1998. Modality's semantic map. Linguistic Typology 2. 79-124.

Verstraete, Jean-Christophe. 2005. The semantics and pragmatics of composite mood marking: The Non-Pama-Nyungan languages of Northern Australia. Linguistic Typology 9. 223-268.

Vuillermet, Marine. 2018. Grammatical fear morphemes in Ese Ejja: Making the case for a morphosemantic apprehensional domain. Studies in Language 42. 256-293. 